\title{
REVISIÓN CRONOESTRATIGRÁFICA DE LA CUEVA DE LA GÜELGA (NARCIANDI, ASTURIAS). DEL MUSTERIENSE AL PALEOLÍTICO SUPERIOR INICIAL
}

\author{
Chronostratigraphical revision of La Güelga Cave \\ (Narciandi, Asturias). Mousterian and Initial Upper Paleolithic
}

\author{
José Manuel Quesada López y Mario Menéndez Fernández*
}

Recibido el 15 de octubre de 2009. Aceptado el 15 de diciembre de 2009.

\begin{abstract}
Resumen. Con este trabajo queremos presentar algunos de los datos más recientes sobre la estratigrafía y la cronología radiométrica de la Cueva de La Güelga (Narciandi, Asturias), con un particular interés por las descripciones sedimentológicas, las industrias y las dataciones cronológicas, en relación con los orígenes del Paleolítico Superior y muy especialmente con el Paleolítico Medio.

Palabras claves: Paleolitico Medio, Paleolitico Superior, Auriñaciense, Chatelperronense, Musteriense, Neandertal, Cornisa cantábrica.
\end{abstract}

Abstract. In this paper we want to present some more recient results related to the stratigraphy and ${ }^{14} \mathrm{C}$ chronology of the La Güelga Cave (Narciandi, Asturias), with major interest about sedimentological descriptions, industries and chronological datations, relations with the origins of the Upper Paleolithic and specially with the Middle Paleolithic.

Key Words: Middle Paleolithic, Upper Paleolithic, Aurignacian, Chatelperronian, Mousterian, Neanderthal, Cantabrian area.

\section{PRESENTACIÓN}

\section{DIEZ AÑOS DE TRABAJO EN LA GÜELGA}

Diez años han transcurrido desde que comenzamos un ambicioso programa de investigación en la Cueva de La Güelga (Narciandi, Asturias), dirigido a indagar en la primera secuencia de ocupación paleolítica del lugar. Este programa pretendía colaborar en la investigación de una cuestión muy polémica por aquellos años: la transición entre el Paleolítico medio y el Paleolítico superior. Era el año 2000 cuando iniciamos la primera campaña de campo y trazamos un sondeo pequeño en una especie de terraza que se elevaba unos $9 \mathrm{~m}$ sobre el cauce actual del arroyo que surca la cueva. La cata era modesta pero el hallazgo de restos chatelperronenses proporcionaron grata sorpresa y comprometió los trabajos posteriores en el yacimiento. La presencia de estas piezas permitía en principio incorporar La Güelga en la nómina de yacimientos cantábricos que polemizaban entonces en la complicada discusión académica acerca de la transición Musteriense - Paleolítico superior. Eran momentos de controversias exacerbadas y encendidas que el paso del tiempo han calmado y orientado por sendas de discusión más sosegadas y más templadas.

Fue de ese modo cómo se inició una investigación a largo plazo, un programa que ha transcurrido a lo largo de ocho campañas de campo y que nos ha permitido reconstruir la compleja historia geoarqueológica y las vicisitudes de tipo cultural que ocultaba el yacimiento de aquella terraza. En torno al 2004/2005 publicamos algunos de los resultados provisionales obtenidos en las cuatro primeras campañas, que no pasa de ser noticias preliminares para anticipar algunas de las impresiones generales. Eran dos artículos pre-

(*) Dpto. Prehistoria y Arqueología UNED. Po. Senda del Rey, 7.28040 Madrid. e-mail: jmquesada@geo.uned.es y mmenéndez@geo.uned.es 
sentados ante la opinión especializada aprovechando dos reuniones científicas sobre el estado de la cuestión sobre los neandertales cantábricos. El primero se puede consultar en el voluminoso tomo de las comunicaciones que se presentaron en la conocida Reunión Científica titulada "Neandertales cantábricos, estado de la cuestión" (Menéndez, Garcia y Quesada, 2005). El segundo artículo es básicamente una versión reducida del trabajo anterior, y puede consultarse en las actas de las Jornadas de trabajo tituladas El ocaso de los Neandertales", organizadas para conmemorar el Centenario del descubrimiento de la cueva de El Castillo (Menéndez, García y Quesada, 2006).
En aquellos momentos disponíamos de datos parciales y de una imagen todavía muy preliminar de lo que se ha revelado una secuencia estratigráfica con una génesis relativamente compleja. En la actualidad el bagaje de información recopilado tras otras cinco campañas de trabajo y una intensa labor de laboratorio, permite y exige reconsiderar algunas de aquellas propuestas iniciales. Es por tanto una ocasión inmejorable para revisar y replantear desde una perspectiva autocrítica la secuencia arqueológica de la "transición» en La Güelga, a la luz de nuevos datos geoarqueológicos, cronoestratigráficos y por supuesto industriales. La presencia de niveles de una cronología apro-

Situación de la cueva de La Güelga (Asturias)

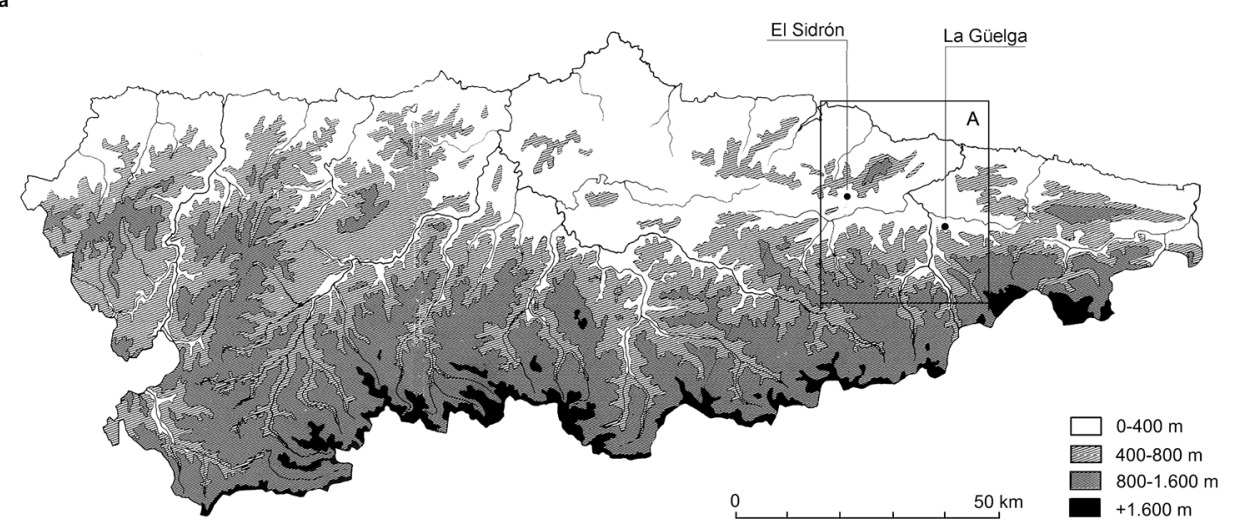

A: Detalle de la zona recuadrada (Cuenca del Sella)

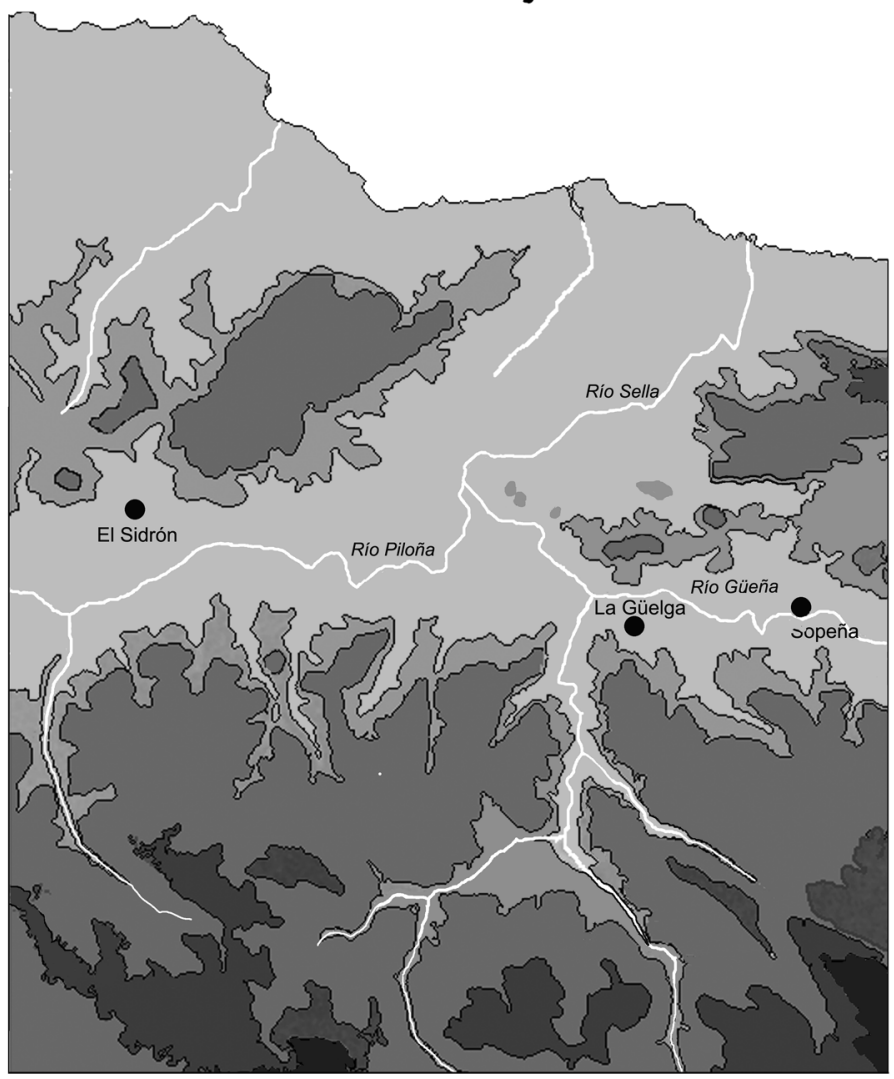

Plano de detalle: Entorno de La Güelga

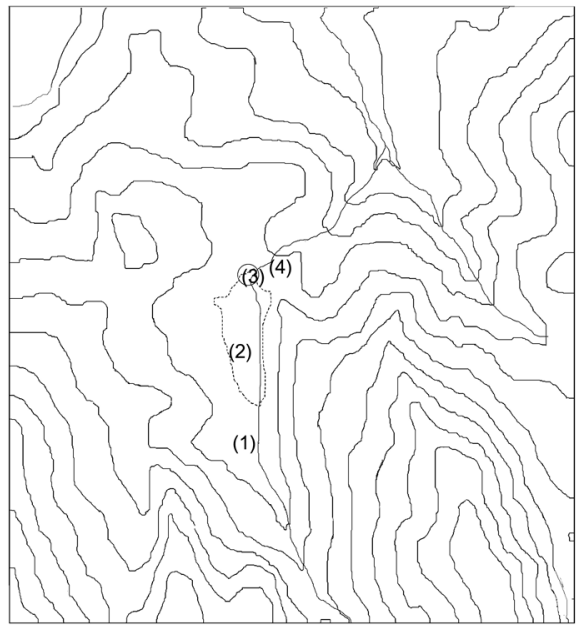

(1) Arroyo de la Brava

(3) Boca de la cueva

(2) Dolina de La Güelga

(4) Karst (recorrido interior del arroyo)

A Figura 1. Situación y emplazamiento de la Cueva de La Gúelga. 
ximada en otros yacimientos de la región (fig.1) redunda más si cabe en la necesidad de revisar la secuencia de La Güelga de cara a futuras investigaciones. En las siguientes páginas resumimos las principales reflexiones que hemos meditado a lo largo de estos años, matizamos de manera oportuna varias de las hipótesis provisionales y proporcionamos un encuadre ya muy ajustado de lo que fueron las ocupaciones paleolíticas de esta cueva entre el 50.000 y el 30.000 B.P. ${ }^{1}$.

\subsection{Las zonas arqueológicas del yacimiento}

La Cueva de La Güelga se abre en la pequeña vaguada de un arroyo llamado de La Brava², que con el paso del tiempo ha erosionado el terreno y con ello dejado testigos arqueológicos a ambas vertientes de la hondonada fluvial. Los testimonios de ocupación paleolítica se conservan en varias zonas, en relación con los habituales procesos geoarqueológicos de sedimentación y erosión, que caracterizan los yacimientos kársticos. De una parte, quedan los retazos de habitación básicamente magdalenienses en la orilla izquierda, más o menos a la altura actual del riachuelo. Pero hay también un importante yacimiento en la orilla derecha, una larga y extensa secuencia del Paleolítico medio (con rastros más desvaídos de Paleolítico superior inicial) colgado a varios metros del arroyo actual, en una zona que antiguamente albergaba la boca de la caverna. Esta es la distribución de restos arqueológicos que hemos reconocido en el lugar (fig.2):

La zona A. Está situada junto a la orilla izquierda del cauce, apenas a 2-3 m de distancia del desmonte o corte que limita la hondonada por la que circula el cauce del arroyo. La zona es una pequeña plataforma prácticamente plana, pero que originalmente poseía una pendiente E-O. Esta desapareció por la intervención humana: no en vano, la zona fue parcialmente desmantelada, en parte vaciada y más tarde allanada para organizar un redil de ganado caprino. De esta manera se levantó una "muria" o muro de piedras que cercó el aprisco y se sustentó sólidamente en ciertos puntos sobre el mismo suelo calizo de la cueva. El resultado es un espacio angosto de 3 metros de ancho por 8 de largo, delimitado entre la pared caliza de la cueva y la muria. Esta zona fue objeto de una serie de campañas de excavación entre los años 1990-1995, que exhumaron niveles del Magdaleniense inferior tipo Juyo (Menéndez y Martínez, 1992a, 1992b; Menéndez, García y Quesada, 2004, 2005, 2007).

La zona B. Localizada en la orilla derecha del cauce, tan solo 2-3 m de distancia del corte y separada de la zona $\mathrm{A}$ por la pared del cobertizo descrito. En realidad constituye la prolongación natural hacia el exterior de la zona A: por tal razón es una buena reserva arqueológica para conocer los depósitos arqueológicos desmantelados en el aprisco. Máxime cuando no ha sufrido las lamentables acciones de nivelado para la construcción del cobertizo. La plataforma aterrazada conserva una pendiente $\mathrm{E}-\mathrm{O}$ y se extiende a lo largo de unos $6 \mathrm{~m}$ hasta el desmonte de la hondonada. Durante los años noventa se realizó un pequeño sondeo arqueológico, próximo a los $4 \mathrm{~m}^{2}$, que dio cuenta de una serie de niveles magdalenienses en una cota superior a las registradas en la zona $\mathrm{A}$.

La zona $\mathrm{C}$. En la vertiente derecha del valle se encarama la zona $\mathrm{C}$. Esta localizada junto al mismo corte de la hondonada fluvial, a una altura de $2 \mathrm{~m}$ sobre el fondo del cauce del pequeño arroyo. Se trata de una superficie angosta de unos $4 \mathrm{~m}$ de ancho por $12 \mathrm{~m}$ de largo aproximadamente. Desconocemos la relevancia arqueológica de la zona pues no hemos realizado intervención arqueológica ni hemos detectado restos prehistóricos en su pequeña planta. Hemos de tener en cuenta que parte de esta terraza está cubierta por un amplio depósito de ladera y que la pared anexa de la cueva conserva las huellas de procesos fluviales que podrian haber intervenido como agentes erosivos de los depósitos.

La zona $\mathrm{D}$. Desde la plataforma de la zona $\mathrm{C}$ se accede con cierta facilidad a la zona $\mathrm{D}$, remontando la empinada ladera que se cierne por encima. La senda que recorre la rampa conduce a una pequeña plataforma a una altura de $+9 / 11 \mathrm{~m}$ sobre el nivel actual del arroyo. Desde allí existe una buena vista de la boca actual de la cueva y la vereda arbolada del cauce fluvial. La zona D es una superficie aterrazada de una anchura relativamente angosta pues no se extiende más de unos 3-5 m entre el talud de la ladera que vierte hacia el cauce y la pared oriental de la cueva. La terraza se aleja de la pared frontal de la cueva hacia el S. a lo largo de 10-12 m, paralelamente al desarrollo que sigue el cauce del arroyo ladera abajo. El perfil E-O de la terraza tiene una pendiente de unos $5 \mathrm{~m}$, entre la pared de la cueva y un brusco talud que da pie a la ladera, que se suaviza paulatinamente a medida que nos alejamos de la cueva en dirección $\mathrm{S}$.

(') Estos trabajos han sido posibles gracias a la financiación otorgada por la FICYT del Principado de Asturias, a través del proyecto PC06-051, "El final de los Neandertales y la primera humanidad moderna en la cuenca media del Sella", desarrollado entre el 1-12-2006 y el 30-11-2008.

(2) El Arroyo de la Brava no es más que un pequeño reguero de marcado carácter estacional, cuyo nacimiento está en las primeras estribaciones del Precornión, que se elevan frente a la cueva. Su cauce desciende con gran caudal en invierno; alcanza su máxima cota en primavera con el deshielo; y aparece habitualmente seco en la temporada estival. La ausencia de caudal en los alrededores de la cueva es muy habitual porque pocos metros antes de la boca, las aguas se precipitan por un sumidero. Las aguas subterráneas Ilegan hasta un pozo situado en la galería principal de la cueva, que en los veranos húmedos actúa como sifón. 
Croquis esquemático de situación de La Güelga

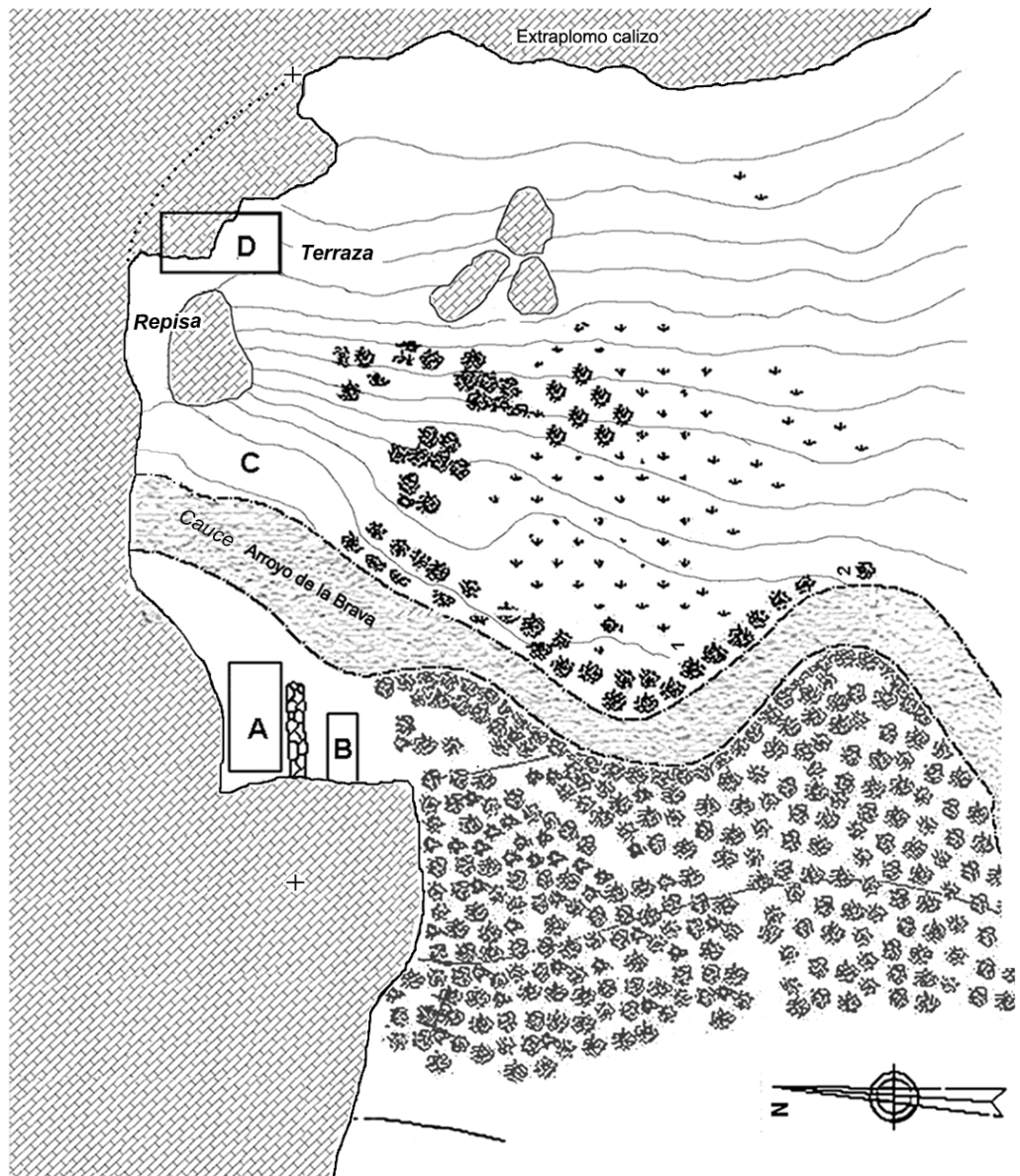

La zona $D$ se ubica en una plataforma aterrazada a unos 9-11 $m$ de altura sobre el cauce actual del arroyo, en la ladera derecha. Justo por encima de la planta de excavación se levanta el paredón exterior actual de la cueva (ver extraplomo calizo), un tajo vertical que configura una especie de anfiteatro y que resultó del desplome de la antigua visera. Los restos de este desplome se pueden ver en la planta de esta imagen como grandes masas calizas desperdigadas por la ladera de manera caótica.

Junto a la zona $D$ se halla una especie de repisa, que conserva un depósito todavía sin excavar en conexión con la secuencia estratigráfica de la zona $D$ interior. Así como una terraza, que conserva la misma secuencia registrada en la zona $D$ exterior.

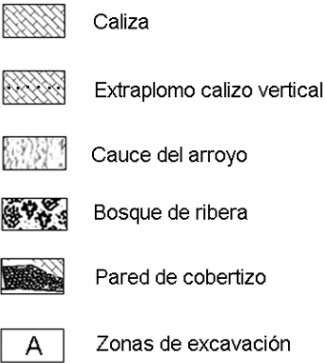

- Figura 2. Planimetría (croquis) de la Cueva de la Güelga.

Las altas paredes calizas que rodean la zona D presentan una silueta muy peculiar: nos hallamos ante un farallón vertical que ha seccionado el antiguo karst de modo contundente, una especie de anfiteatro cortado a tajo que se prolonga durante $10 \mathrm{~m}$. hacia el sur. El tajo no es más que el resultado de un intenso proceso de crioclastia, que provocó el desmoronamiento masivo de lo que antaño fuera una gran visera caliza que se prolongaba varios metros hacia el exterior y que proporcionaba un excelente refugio para las ocupaciones humanas. Restos de la visera aparecen dispersos por la ladera, en posición caótica; bloques de varias toneladas desprendidos desde lo alto, que han rodado por la pendiente, llegando incluso hasta la hondonada del arroyo.

En realidad la zona $\mathrm{D}$ no es más que una parte de un yacimiento mucho más amplio: nos hallamos ante una área reducida de un depósito que se prolonga notablemente, no solo por la plataforma aterrazada al aire libre sino por debajo de las masas calizas próximas. Estas masas ocultan un importante depósito que se desparrama ampliamente por el inte- rior de la caverna, por una sala accesible actualmente tan solo a partir de galerías laterales, pero que antaño era un vestíbulo relativamente diáfano y conectado cómodamente con una no menos extensa apertura. La sala en cuestión constituye en realidad parte de la más antigua boca de la cueva, la entrada originaria del sistema kárstico hasta hace unos 30.000 años grosso modo. Pero el encajonamiento fluvial del valle dejó colgada aquella primitiva boca; los procesos de drenaje dejaron de intervenir y distintos fenómenos de crioclastia y solifluxión provocaron su cierre y su completa colmatación. El yacimiento desapareció hacia el exterior de tal manera que las primeras búsquedas por la terraza que realizamos a mediados de los años noventa no tuvieron ningún éxito: nada quedaba en superficie de aquel yacimiento arqueológico. Pero lo cierto es que las primeras valoraciones topográficas de la caverna avalaban la existencia en aquel lugar (más o menos junto a un paquete de grandes masas calizas pegadas a la pared norte de la cueva) de la que en tiempos había sido la más antigua entrada de la caverna. 


\subsection{El yacimiento del vestíbulo interior}

La presencia de un depósito paleolítico oculto en el interior de la cueva era sobradamente conocida entre los lugareños desde hacía mucho tiempo. Pero la primera comunicación cientifica al respecto es bastante reciente pues se remonta a mediados de los años ochenta, cuando la cueva se incorpora en el inventario de la carta arqueológica de los concejos de Cangas de Onís y Onis (Martínez Villa, 1986).

En los primeros años noventa, una oleada de visitantes embarcados en las excitantes aventuras de lo que se ha llamado "turismo activo", convirtió la cueva en lugar ideal para el furtivismo arqueológico. En el recorrido guiado por las galerías iniciales de la cueva los guías espeleológicos conducían a los turistas hasta la sala interior: llegados a este punto se hacía el pertinente alto para conocer de primera mano lo que era un yacimiento prehistórico, y de paso llenar los bolsillos con algunas de las muchas piedras y huesos que cubrian el suelo. Esta labor, repetida con el largo discurrir de los turistas, ha acabado esquilmando la extraordinaria riqueza superficial de restos arqueológicos, algunos de los cuales eran desechados nada más salir de la cueva.

En realidad, la riqueza material en superficie que ofrecía el vestíbulo era tal que bastaban solo un par de pasos para reconocer a simple vista el manto ingente de huesos y lascas que se desparramaba en derredor. Es aquella una sala de grandes dimensiones por su notable anchura y su no menos recorrido longitudinal. En sus tiempos la sala era con toda probabilidad un vestibulo relativamente diáfano con muy buenas posibilidades de habitación, que comunicaba de manera directa y cómoda con el exterior a partir de una amplia boca. En la actualidad, el yacimiento arqueológico interior se distribuye en dos zonas. Hay un espacio bastante llano en la zona más profunda, sin apenas pendiente, que da paso a un cono de deyección que gana pendiente de manera paulatina pendiente a medida que progresamos hacia la boca colmatada. La pendiente resulta muy suave al principio pero termina con una pared vertical de sedimentos en su tramo superior que alcanza la bóveda de la caverna.

La riqueza arqueológica del yacimiento interior no solo se podía percibir en la capa de restos que cubría por doquier la superficie arcillosa del suelo. Una buena medida de la importancia del yacimiento se puede obtener leyendo una nota periodística publicada hace treinta años en la prensa local. La noticia propagaba el hallazgo de una magnífica defensa de proboscídeo, que alcanzaba al parecer hasta un metro de longitud y poseía un grado de conservación excepcional. Tan asombrosa pieza fue recuperada por un aficionado a la ar- queología en una cata de $4 \mathrm{~m}^{2}$ y $40 \mathrm{~cm}$ de profundidad en la sala interior. En la actualidad, todavía existe aquel agujero que se conserva en un rellano sobre la margen derecha de la sala. La noticia publicada en la revista "Asturias Semanal» incorporaba una fotografía en la que se da buena muestra de la importancia del hallazgo, en la que aparece el feliz arqueólogo ocasional, portando en su regazo la fabulosa pieza. En la actualidad, lamentablemente, el colmillo en cuestión se halla en paradero desconocido.

En realidad, hoy en día poco queda de la riqueza arqueológica que exhibía a simple vista la sala interior. La insistente visista de furtivos aficionados de los noventa terminó por esquilmar de cuarcitas y huesos la superficie arcillosa del terreno. De aquella riqueza quedan retazos superficiales de restos entre los perfiles laterales del cono de deyección. Por fortuna, la regulación de las visitas por las autoridades locales permitió acabar con tan funestas prácticas aficionadas. Pero fue entonces cuando aparecieron problemas de un mayor calado. En torno al 2000 pudimos apreciar la huella de intervenciones intensas de furtivos especialistas: eran agujeros realizados de manera sistemática, metódica y planificada por toda la sala y por buena parte del cono. Estas acciones revelaban un reconocimiento meticuloso del terreno pues iban acompañadas de señales pintadas estratégicamente sobre paredes y techos, por lo que respondian probablemente a un marco de furtivismo de piezas selectivas. De modo que se hicieron agujeros no solo en la superficie plana del fondo sino también en el tramo superior del mismo. En el tramo final del cono de deyección se dedicaron a rebañar parte de la estratigrafía, precisamente en aquellos sitios pertenecientes a los lentejones con mayor contenido orgánico ${ }^{3}$.

Conscientes de esta impunidad y del peligro de deterioro irremediable del lugar, procedimos al cierre interior de la sala mediante una verja de hierro. El trabajo parece haber cumplido perfectamente su objetivo hasta el día de hoy, y permite contemplar el futuro de conservación de la cueva con mejores expectativas.

\section{HISTORIA DE LA INVESTIGACIÓN}

El propósito principal del programa de investigación en la Cueva de La Güelga se dirigía a la excavación de la zona D, para acceder de esa manera hasta el depósito arqueológico que colmataba la más antigua boca de la cueva (fig.3). En este marco de investigación, las primeras acciones de trabajo, realizadas en el año 2000, tenían como objetivo pri-

(3) Disponemos de una datación ${ }^{14} \mathrm{C}$ para el tramo superior del cono de deyección interior. La muestra de hueso procedia de uno de los lentejones negruzcos que aparecían en el perfil frontal. El resultado obtenido por ${ }^{14} \mathrm{C}$ convencional suministró un $32.000 \pm 1.600 / 1350$ (Grn-18256) (Menéndez, García y Quesada, 2005: 593-594). El resultado se consideró entonces como posiblemente válido, pero en hoy en día, a la luz de los niveles musterienses localizados en la zona D interior, la datación resulta poco convincente y deber ser rechazada. 
Alzado longitudinal de la zona D (Perfil N-S)

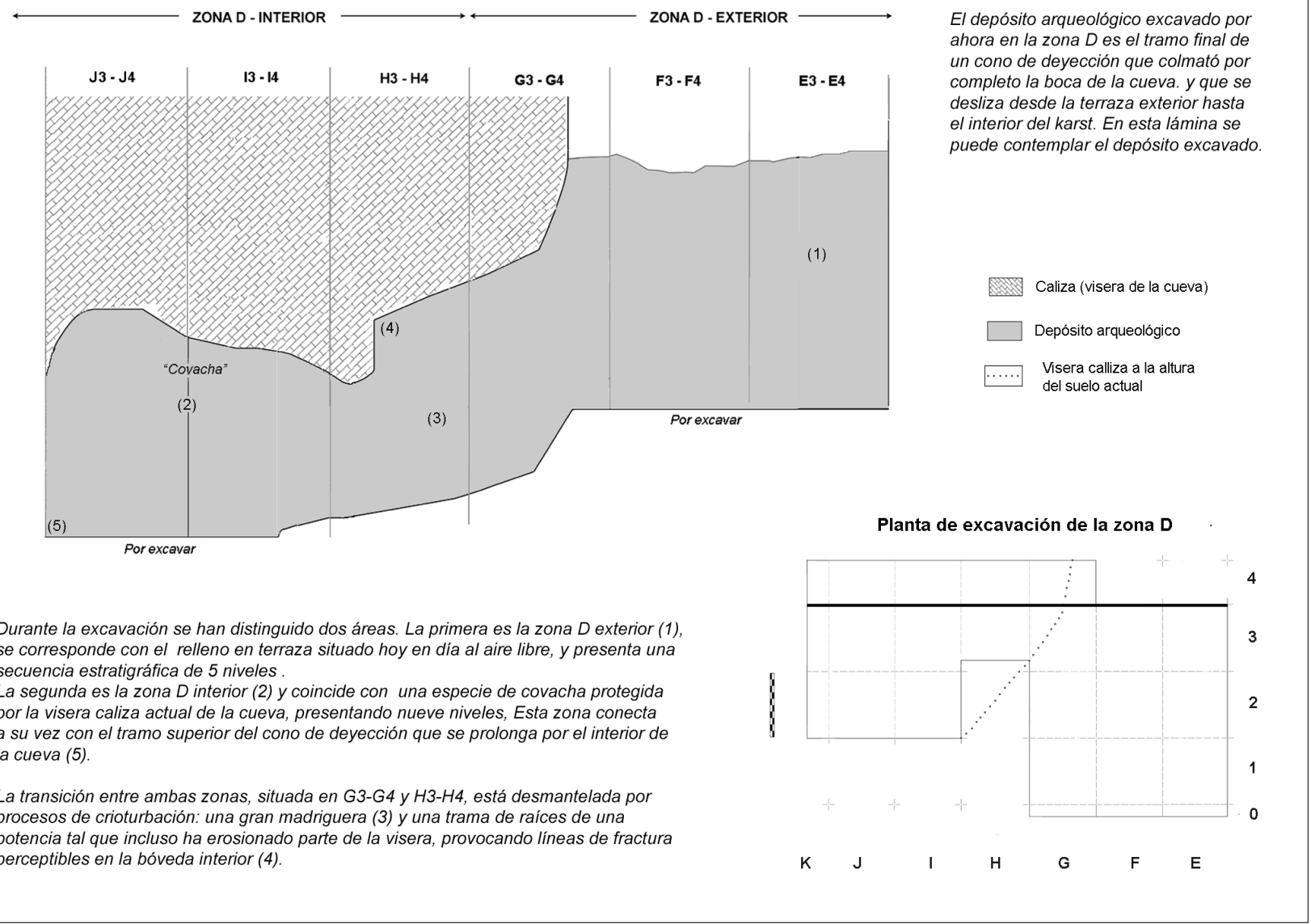

A Figura 3. Perfil longitudinal de la zona D (alzado N-S del depósito excavado).

mordial localizar el emplazamiento de la boca colmatada de la terraza $+11 \mathrm{~m}$. Tanto la restitución topográfica inicial como el estudio de la topografía de la zona parecían avalar la existencia de una boca oculta, de una abertura colmatada de sedimentos. Las hipótesis se concentraban en un recodo protegido bajo un saliente de la pared caliza pues aunque no había rastro de una boca sí apreciamos en las paredes lo que parecian pequeñas concavidades provocadas por flujos erosivos en relación con corrientes hidráulicas. Fue así cómo comenzaron los trabajos arqueológicos en el verano del año 2000, abriendo una cata de $2 \mathrm{~m}^{2}$, justamente enfrente de las pequeñas hornacinas de la pared caliza.

Los trabajos arqueológicos en la zona $D$ comenzaron en el verano del 2000 con la apertura de una pequeña planta de $2 \mathrm{~m}^{2}$, pegada a la pared caliza y frente a las pequeñas concavidades citadas. Las sospechas sobre la presencia de una boca colmatada en el lugar pronto comenzaron a adquirir visos de realidad, al comprobar que las paredes calizas dejaban paso a una oquedad rellena de sedimentos. Estos penetraban hasta $1.5 \mathrm{~m}$. hacia el interior y $0.5 \mathrm{~m}$ en espesor. Tan inmejorables expectativas motivaron la prolongación de los trabajos en tal lugar durante la campaña de 2001. Los cua- dros despejados en la primera campaña (I1-J1) permitieron abordar el trabajo en el interior de lo que parecía ser una covacha. $Y$ así decidimos centrar los operativos en dos cuadros más internos (12- J2), con el propósito de avanzar paulatinamente hacia el interior del karst. Los trabajos de 2001 confirmaron la existencia de dos depósitos (niveles 1-2), cuyas amplitudes avalaban sin lugar a dudas la presencia de la antigua boca. En este marco, la recuperación de una punta de Chatelperron típica abría unas expectativas aún más interesantes si cabe. Durante aquella campaña aún se hallaron dos depósitos más (niveles 3 y 4), pero de poca relevancia arqueológico. Al finalizar la campaña el relleno de esa cavidad en su punto más profundo ya se aproximaba al $1.20 \mathrm{~m}$ respecto de la cota inicial de trabajo. El techo y las paredes se abrian en el interior y parecian ampliar aquella covacha hacia el $\mathrm{N}$ y $\mathrm{E}$.

Los trabajos de campaña desarrollados durante el año 2002 permitieron descubrir la serie de niveles 4-5-6 en la zona D interior. La planta se fue ampliando de manera paulatina a medida que la pared y el techo de aquella "covacha" penetraban hacia el fondo, de tal manera que a finales de tal campaña contábamos con una superficie próxima a los 
5.5. $\mathrm{m}^{2}$. Esta nueva serie de niveles aparecian intactos en los sectores centrales de la planta, pero alterados en los sectores periféricos por distintos procesos de bioturbación. En todo caso las cicatrices erosivas eran lo bastante claras como para permitirnos determinar con precisión los límites de las áreas intactas y garantizar de esta manera las adscripciones industriales de cada depósito. Desde el punto de vista industrial, el nivel 6 proporcionó nuevas sorpresas: la recuperación de restos de clara filiación auriñaciense en la zona más intacta añadía una mayor controversia a la secuencia completa del depósito, que ya alcanzaba el $1.50 \mathrm{~m}$ desde la cota actual del suelo. Esta potencia confirmaba la importancia del relleno y su probable contacto con el cono de deyección interior.

Durante la campaña del 2002 se iniciaron los trabajos en la zona colindante ubicada al aire libre. Tras una primera campaña de sondeo a finales de primavera, junto al talud de la ladera (lo que es el cuadro E2), en septiembre decidimos abrir una planta de unos $2 \mathrm{~m}^{2}$ en una zona contigua al covacho colmatado, junto a la pared caliza amparada al sur. Esta zona se situaba al aire libre y por ello decidimos denominar la cata como zona $\mathrm{D}$ exterior. No obstante sospechábamos que tal zona estuvo antaño protegida bajo la visera caliza que conformaba la antigua boca. Las primeras tareas de exhumación se centraron en los cuadros F3 y G3 y permitieron confirmar una secuencia estratigráfica muy distinta de la registrada en la zona de la "covacha" o zona D interior. En esos dos cuadros, bajo una mínima capa superficial se sucedian hasta tres niveles de relleno masivo, con matriz arcillosa bastante similar y escaso contenido arqueológico, con una apariencia industrial musteriense. Por otra parte, las discrepancias estratigráficas entre dos zonas contiguas motivaron nuevas incertidumbres cuya solución no resultaria inmediata pues ya entonces los sectores que permitían resolver la correlación (en la zona de contacto D exterior / D interior) aparecian afectados por procesos de removilización. Por debajo del nivel 3 aparecía un nuevo depósito con clastos y con numerosos restos de hueso e industria, que constituía al parecer un cambio importante en la sedimentación y que abría paso a un importante nivel de ocupación humana.

En la campaña del año 2003 continuaron las tareas en la zona $\mathrm{D}$ interior. Los trabajos exhumaron un depósito de derrumbe (nivel 7), y una capa de arcillas arenosas (nivel 8) que ocupaba una planta de $2,75 \mathrm{~m}^{2}$ y que mostraba indicios interesantes de incremento de la actividad antrópica. Pero durante ese año de 2003 una buena parte del trabajo de campo se centró en la zona $\mathrm{D}$ exterior, con el propósito de ampliar la planta inicial de trabajo y disponer de un marco de estudio de mayor calidad. Partiendo de los $2 \mathrm{~m}^{2}$ del sondeo inicial se decidió ampliar la planta otros $4 \mathrm{~m}^{2}$ de cara a contar con una superficie más representativa ${ }^{4}$. La ampliación se debió a la escasa resolución del sondeo inicial y la presencia de un pozo revuelto en uno de los cuadros (ver plano de la planta de ese año, Menéndez, García y Quesada, 2005: 600), que redujo aún más si cabe la operatividad de los trabajos de excavación. De modo que dos cuadros ampliaban la planta hacia el sur (F3 y E3) y otros dos la extendian hacia el oeste (F2 y G2). Los resultados obtenidos de tal ampliación permitieron de una parte verificar la secuencia registrada en el año anterior, compuesta por tres niveles arcillosos rojizos y un nivel de derrumbe. Pero mostraron de otra parte la relativa complejidad de los procesos diagenéticos, ya que en algunos cuadros (F2-G2) aparecieron enormes bloques de caliza que parecian responder a una serie de procesos muy intensos de crioclastia, relacionados probablemente con el desmantelamiento de la antigua visera que cubría la zona.

El levantamiento de los primeros bloques calizos no se hizo hasta la campaña del 2005 y desveló la superficie principal de habitación arqueológica hallada en la zona D exterior. La primera imagen que se desprende de tal ocupación es la de una capa generalizada de clastos por la totalidad de los cuadros, con una acumulación intensa de restos arqueológicos, huesos fragmentados e industria. Al despejar los primeros grandes bloques, la zona ganó superficie de trabajo: se ampliaron tres cuadros más hacia el $0(\mathrm{E} 1-\mathrm{F} 1-\mathrm{G} 1)$ y además se pudo rebajar más allá del talud que iniciaba la pendiente de la ladera (E0-F0-G0). De esta manera, la planta total de excavación en la zona D exterior ya era superior a los $9 \mathrm{~m}^{2}$. Despejados los grandes bloques procedimos a la excavación del nivel de ocupación, una capa que se correspondía con los niveles $4 a-4 b$, y que por su enorme cantidad de bloques calizos, por los retazos de brechas y la alta densidad de restos arqueológicos, se presentaba como una tarea muy larga y costosa. El incremento de la densidad de materiales también se registró en la zona $\mathrm{D}$ interior, donde las excavaciones dieron con un nuevo depósito (nivel 9) de inmejorables expectativas: una capa de lentejones carbonosos con restos arqueológicos que parecian avalar un marco de combustión con un grado excelente de conservación.

La excavación de la planta completa del nivel 4, tanto de su parte superior (4a) como de su tramo inferior (4b) ha llevado el total de cinco años. El complicado palimpsesto de huesos, industria y cantos de todos los tamaños, ha dificultado notablemente los trabajos meticulosos de excavación, que se han realizado con los protocolos más estrictos tanto de recogida in situ como de laboratorio. La alta concentra-

(4) La ampliación de la planta de excavación provocó un reordenamiento de las coordenadas: se reunieron las dos zonas de excavación bajo una misma coordinación y tomando como punto central los límites meridionales de la plataforma aterrazada +9-11 m (ver la figura 2). No obstante, los dibujos del perfil de la zona D interior publicados en los trabajos del 2005 y 2006 todavía mantienen la disposición originaria, previa a esta reorganización. 
ción de materiales arqueológicos, la intensa acumulación de bloques y los retazos de brechas demoraron sobre todo las campañas del 2005-2008. En el año 2005 realizamos además un sondeo en uno de los cuadros más próximos a la ladera (G1) que nos permitió valorar la potencia del nivel 4 y apreciar la secuencia subyacente. De acuerdo con este sondeo, por debajo del nivel $4 b$ aparece un depósito estéril muy potente, que permite deslindar con nitidez la ocupación principal de la zona $\mathrm{D}$ hasta el momento.

En la actualidad, la planta total de excavación de toda la zona D (interiory exterior) ocupa unos $17 \mathrm{~m}^{2}$, lo que proporciona una muestra aceptable para reconstruir el modelo general de la secuencia estratigráfica. La idea inicial de distinguir las dos zonas de excavación partía de una simple di- ferenciación topográfica, pero con el paso del tiempo se ha manifestado como una solución adecuada para la reconstrucción estratigráfica, ya que buena parte de las secuencias no guardan correlación estricta. Por esta razón, la descripción estratigráfica de la zona $D$ requiere un análisis diferenciado, y como tal procederemos a continuación.

\section{LA ZONA D INTERIOR: LA SECUENCIA ESTRATIGRAFÍA E INDUSTRIAL}

Los trabajos que hemos realizado en la zona $D$ interior han descubierto por ahora una secuencia de más de $2 \mathrm{~m}$ de potencia total (fig.4), que conectan directamente con el

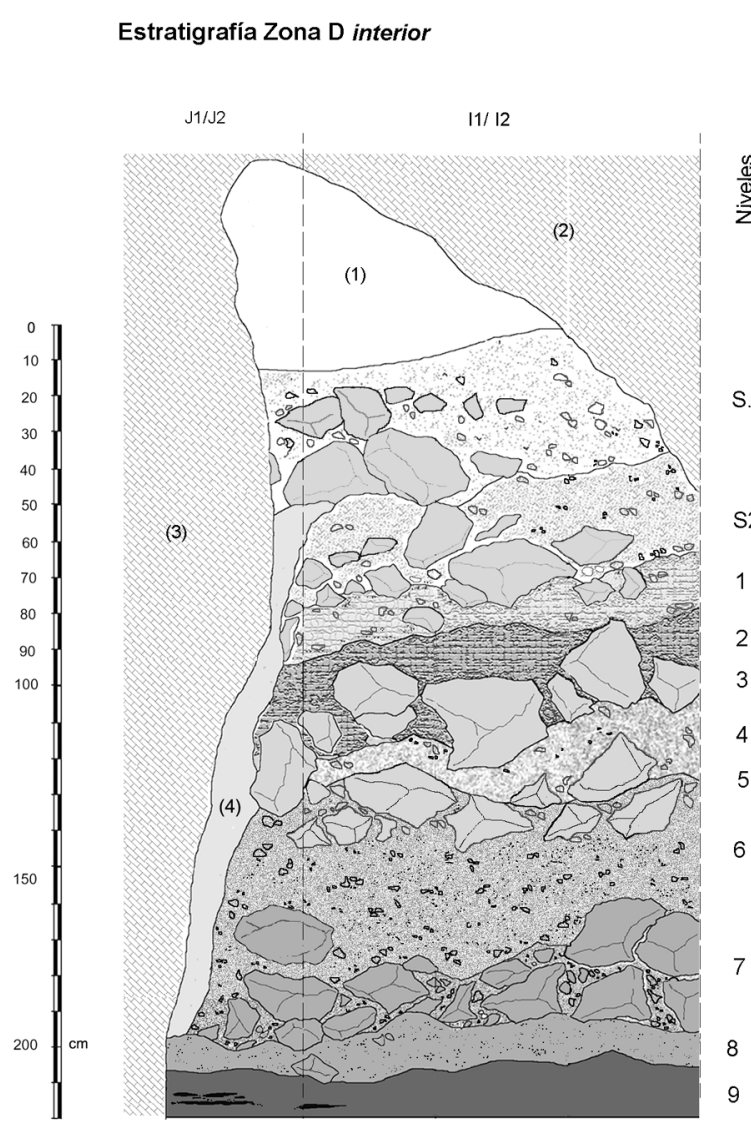

El perfil estratigráfico más claro de la zona $D$ interior se localiza entre los cuadros 11/12, un corte distante de los sectores más afectados por los procesos de removilización descritos en el texto. Este perfil revela cómo la covacha estaba colmatada exceptuando una pequeña abertura poco profunda expuesta al aire libre (1). El corte señalado coincide con la vertical exterior del extraplomo calizo que separa la zona $D$ interior y lo que llamamos a"repisa" (2).

La secuencia estratigráfica consta de dos niveles superficiales revueltos y nueve niveles de distintas adscripciones industriales (Chatelperronense, Auriñaciense y Musteriense). Entre los niveles con restos culturales se intercalan niveles estériles de diverso signo. En la margen izquierda, la secuencia estratigráfica aparece interrumpida por una columna caliza que descuelga del techo (3). Junto a ella aparece una removilización por escorrentía, procedente del exterior (4).

S2
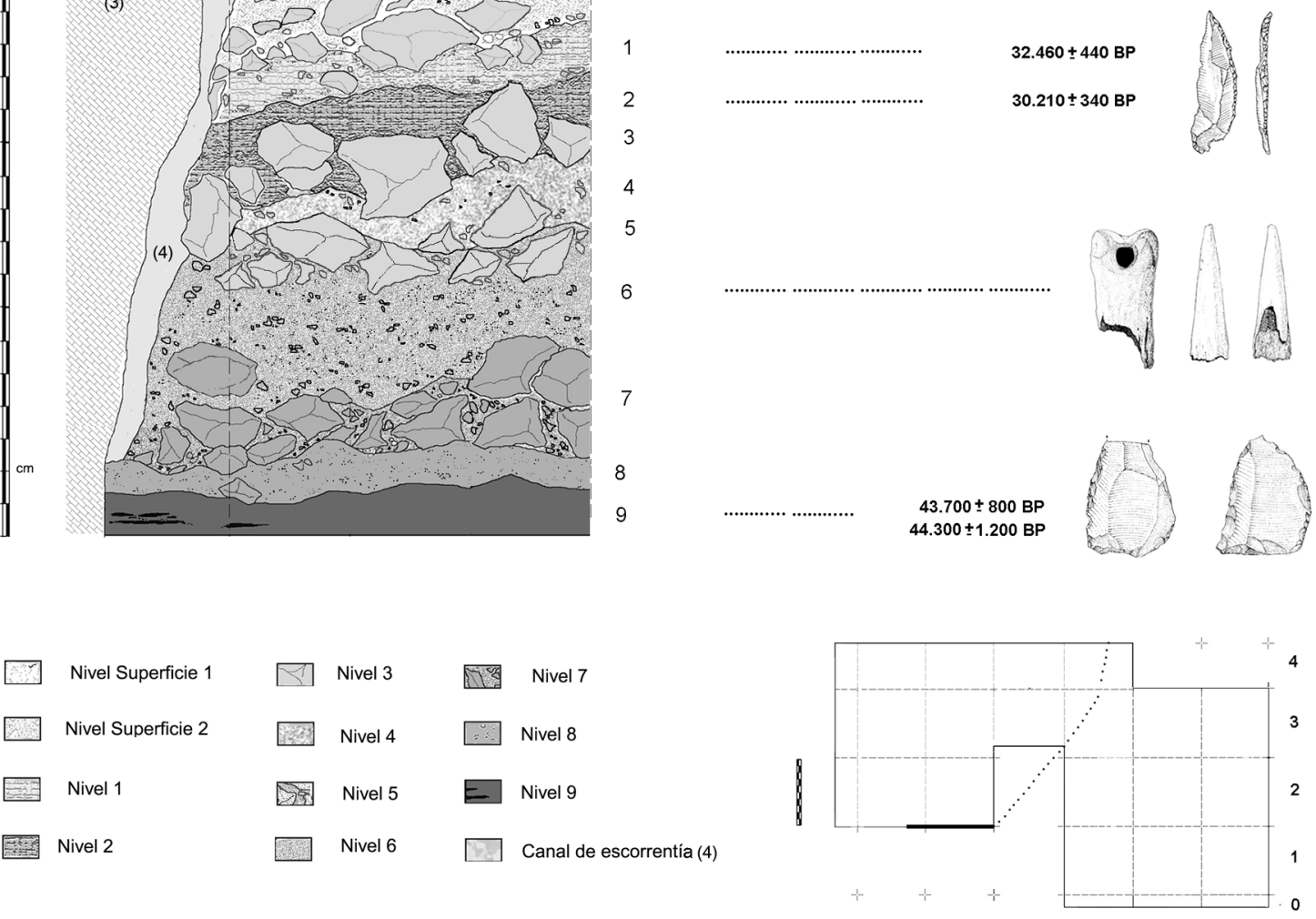

Nota: Los dibujos de piezas no están a la misma escala

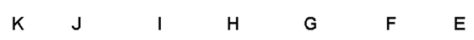

$\Delta$ Figura 4. Secuencia estratigráfica de la zona D interior y dataciones ${ }^{14} \mathrm{C}$. 
tramo superior del cono de deyección que se dirige hacia el interior del kasrt. La extensa secuencia de niveles que hemos excavado en tal lugar rellena una pequeña cavidad o covacha: un espacio ciertamente angosto amparado por una bóveda cóncava en el techo y por unas paredes muy pronunciadas. En los inicios del proceso de acumulación de sedimentos en la covacha (más o menos a la altura del nivel 9), la colmatación de la boca estaba tan avanzada que el acceso al vestíbulo interior de la cueva era ya muy limitado (quizás ya impracticable).

Los trabajos que hemos realizado desde el año 2000 han exhumado la secuencia de esta zona D interior o covacha. Desde la dimensión estrictamente técnica, se trata de una superficie de excavación bastante pequeña, una planta de poco más de $6 \mathrm{~m}^{2}$ en el mejor de los casos. La superficie útil es mucho más limitada porque en algunos sectores de tal planta hemos detectado una serie de removilizaciones y alteraciones provocadas por los habituales procesos de bioturbación que tienen lugar en zonas de contacto con las paredes de cuevas. La mayor parte se concentran en los sectores periféricos de la planta, aquellos que limitan techo y paredes interiores. Hemos registrado procesos de bioturbación motivados por tres factores: madrigueras de animales; raíces de árboles y enredaderas; y canales de escorrentía por aguas exteriores. Por fortuna, queremos manifestar de una manera contundente que las cicatrices erosivas de las alteraciones eran perfectamente nítidas y pudimos delimitar sin problemas los sectores indemnes, reconocer los sedimentos intactos, y en definitiva separar el material arqueológico asociado, garantizando con toda solvencia la calidad de la información arqueológica en todos niveles.

\subsection{La superficie}

En el techo de la amplia columna estratigráfica reconocida en la zona $D$ interior hemos exhumado un nivel superficial, bastante potente pero de incierta asignación cronológica y cultural. La presencia de restos arqueológicos es bastante considerable para la pequeña planta que ocupaba poco más de $3 \mathrm{~m}^{2}$. Pero tal riqueza pierde valor ante la dudosa pertenencia industrial, que apunta hacia una mezcolanza de materiales de distintas épocas. La presencia de restos líticos de probable cronología paleolítica coexiste con una serie de cerámicas y materiales paleontológicos de pátina muy distinta. Esta peculiar combinación aparece entre una acumulación de restos recientes de micromamíferos y de gasterópodos terrestres. En el medio metro de espesor de este tramo inicial hemos discriminado dos niveles de unos rasgos ciertamente muy parejos.

Nivel superficial 1:

Bajo la bóveda caliza de la covacha aparece un primer nivel superficial. Es un relleno de arcillas pulverulentas de un color marrón más o menos oscurecido, con $30 \mathrm{~cm}$ de potencia media. Entre la matriz se desperdigaban algunos clastos, de manera caótica e irregular: la mayor parte de tamaño medio $(10-20 \mathrm{~cm})$ pero sin faltar algunos pocos de mayor volumen (20-40 cm). El nivel posee un buzamiento en sentido SO-NE, que reproduce el patrón de caída para todo el depósito $D$ interior: es una caída paulatina hacia el interior del karst, relativamente discreta en la banda de los cuadros I, pero con una ruptura de pendiente notable en los cuadros $\mathrm{J} 2$ y J3. El nivel presenta además algunos clastos con las huellas típicas de acción erosiva subaérea.

\section{Nivel superficial 2:}

No hay rastro alguno de discontinuidad estratigráfica entre los dos niveles superficiales. El relleno del nivel Ilamado Superficie 2 presenta rasgos muy similares a los descritos para su homólogo: una matriz arcillosa con cierto carácter pulverulento; una tonalidad marrón; clastos medianos (10$20 \mathrm{~cm}$ ), distribuidos de una manera irregular y caótica; un buzamiento SO-NE. La pendiente de caída es moderada en la banda de cuadros 12 e 13 , pero aumenta de manera progresiva conforme avanzamos hacia los cuadros J2 y J3.

La continuidad estratigráfica entre estos dos niveles y sus notables similitudes sedimentarias permiten considerarlos como una misma unidad estratigráfica. Desde el punto de vista estratigráfico no son más que el relleno terminal de un largo proceso de colmatación de la pequeña covacha. Probablemente en los comienzos de la sedimentación del relleno, la covacha ya se había cerrado en su lado sur, no quedando más una oquedad pequeña tan solo accesible por su vertiente este, por las dos pequeñas hendiduras que identificamos en un primer momento como concavidades calizas. Esta configuración ayuda a valorar la génesis del relleno superficial, que resulta ser un depósito de colmatación moderno de materiales adóctonos arrastrados desde la vertiente NO, desde la pequeña repisa anexa.

Parte de los sectores del cuadro 12 que limitan con el cuadro $\mathrm{H} 2$ presentan los rastros de un proceso de bioturbación, motivado por una gruesa trama de raíces que penetra desde el exterior. Dicha trama parte de un árbol cuyo tronco creció prácticamente adherido a la pared caliza, aprovechando la humedad de escurría por tal pared para prolongar sus raíces hacia el interior del karst. La potente raíz principal penetró inicialmente adherida a la bóveda de la covacha, se introdujo hacia el interior con un empuje suficiente para romper como una cuña parte de la misma (desgajando un bloque de caliza de grandes dimensiones) y finalmente avanzó hacia el interior desbaratando parte del depósito arqueológico de tres sectores.

En los dos niveles hay numerosos materiales modernos. Entre el material paleontológico hemos recuperado restos de gasterópodos terrestres; pequeños huesos de micromamíferos de edad reciente por su estado de fosilización; así como 
restos óseos de cierto tamaño pertenecientes a macromamíferos de edad moderna. Entre los materiales arqueológicos hay algunas piezas líticas de cronología incierta, si bien la valoración cultural de los dos niveles descansa en una serie de fragmentos cerámicos realizados a mano, que pertenecen a un cuenco de cronología problemática (tal vez de época medieval).

\subsection{El Chatelperronense}

La secuencia arqueológica intacta de la zona D interior comienza con dos niveles muy similares, emparejados por una impronta industrial común de filiación chatelperronense. Los rasgos que permiten unificar ambos niveles bajo una sola unidad estratigráfica son numerosos: las semejanzas sedimentarias, la ausencia de discontinuidad estratigráfica y los parecidos industriales. En realidad, la discriminación del nivel 2 obedece a dos pequeños matices, una matriz levemente más compacta y cierta exhibición subhorizontal de los materiales. Pero esos matices no tienen en verdad mucha trascendencia en la caracterización estratigráfica general, y de hecho pierden valor frente a las numerosas coincidencias sedimentarias y culturales. En este sentido la mejor prueba de la identidad de ambos niveles no deja lugar a dudas: hay algunos fragmentos óseos -con bordes fracturados antiguosque remontan a la perfección (véase por ejemplo dos restos de una misma hemimandibula de ungulado).

\section{Nivel 1:}

La impronta industrial de esta unidad estratigráfica reposa en el nivel 1 pues es aqui donde se encuentran las piezas líticas diagnósticas de adscripción chatelperronse. El nivel presenta una matriz arcillosa, levemente terrosa, con una tonalidad marrón un tanto clara. La potencia media oscila entre los $20 \mathrm{~cm}$ en el cuadro 12 y $10 \mathrm{~cm}$ en el cuadro J2. Entre la masa arcillosa son relativamente abundantes los cantos angulosos, que aparecen dispersos por toda la planta y sin un patrón organizado, aunque se detecta una mayor acumulación de clastos en los cuadros J2 y J3. Predominan los clastos de tamaño pequeño $(>10 \mathrm{~cm})$ pero también son numerosos los de medianas dimensiones $(10-20 \mathrm{~cm})$. El nivel presenta el buzamiento convencional de la zona $\mathrm{D}$ interior: una caída en dirección SO-NE, que despliega una pendiente bastante discreta en los cuadros de la banda I, pero que se acentúa de manera paulatina en los cuadros de la banda J. La presencia de algunos cantos rodados de cuarcita y arenisca revela la génesis exterior del nivel.

\section{Nivel 2:}

El nivel 2 muestra numerosas coincidencias con el nivel anterior: su matriz es arcillosa, levemente terrosa, su color marrón claro; su matriz incluye una relativa abundancia de cantos de pequeñas dimensiones $(>10 \mathrm{~cm})$ y ya en menor medida de medio formato $(10-20 \mathrm{~cm})$; la fracción gruesa se distribuye de manera generalizada pero caótica; y por fin, el nivel acusa un buzamiento SO-NE coincidiendo con la pendiente general de caida del relleno hacia el interior del karst. El espesor no supera en el mejor de los casos los $10 \mathrm{~cm}$ (cuadro 12) y adelgaza de una manera paulatina a lo largo del cuadro J2. Entre la masa arcillosa aparecen varios cantos rodados y algunos bloques fragmentados de brechas compactas de pequeñas dimensiones. He aqui dos razones para interpretar el nivel como una aportación desde la repisa exterior (en la que todavía se conservan retazos de ambos niveles sin excavar).

Los dos niveles resultan muy interesantes por contener un repertorio industrial chatelperronense. Pero presentan un inconveniente principal: su limitada distribución en planta, pues no supera los $3,75 \mathrm{~m}^{2}$ útiles de modo que nos hallamos ante una especie de pequeño sondeo. Esta pequeña planta es producto de la reducida superficie de la propia covacha pero también refleja la perniciosa intervención de procesos de removilización que han desmantelado parte de los límites meridional y oriental del cuadro 12 . De una parte, la penetración de una trama de raíces procedente del exterior (continuación de la bioturbacion de los niveles superficiales) ha desmantelado de una manera inclemente parte de la banda meridional de los cuadros 12 e 13. De otra, la penetración de un canal de escorrentía desde el exterior ha erosionado parcialmente algunos sectores del cuadro 12: un angosto canal que profundiza de manera paulatina hacia el interior del karst, aprovechando la pared caliza, progresando como una banda de limos de $5 \mathrm{~cm}$ de anchura en el nivel 1 (que aumenta hasta los $10 \mathrm{~cm}$ en el nivel 2). En este punto, resulta necesario señalar que las cicatrices erosivas originadas por la trama de raíces y por el canal de escorrentía son lo bastante nítidas como para delimitar la amplitud de las áreas removilizadas sin problemas. De tal manera que hemos podido segregar con toda seguridad las áreas intactas, y seleccionar con toda solvencia el material arqueológico asociado. En realidad, la mayoría de las piezas líticas que hemos recuperado en los dos niveles se hallaban lejos de áreas removilizadas y por lo tanto proporcionan las oportunas garantías de integridad estratigráfica.

En esta limitada planta la cantidad de piezas líticas que se han recuperado resulta bastante limitada. Por ejemplo, el instrumental lítico del nivel 1 se reduce solo a una docena de piezas. Por fortuna, este reducido repertorio contiene piezas indiscutibles para la asignación industrial. La pieza más representativa es una punta de Chatelperron de una impronta nítida y unos rasgos tipológicos tan característicos que no presentan duda alguna (Menéndez, García y Quesada, 2005: 595). La punta apareció en una cota elevada del nivel (a $5 \mathrm{~cm}$ del techo) y en un área intacta muy próxima a la entrada de la covacha, prácticamente bajo el arco de la visera actual que limita con el perfil de los cuadros 11 y Jl que conecta con 
la repisa de exterior. Es una punta convencional, estándar, de factura habilidosa y una técnica muy depurada. Está tallada en una lámina estilizada de sílex verdoso bandeado (materia prima muy poco habitual en la comarca). Presenta $5 \mathrm{~cm}$ de longitud y poco más de $1 \mathrm{~cm}$ de anchura. Posee un pequeño rebaje en el extremo proximal y un cuidadoso dorso curvo. El estado de conservación es excelente, hasta tal punto que conserva intacto su ápice distal.

Realmente las piezas de sílex son abundantes en el nivel 1, lo que encaja bastante bien con una impronta industrial chatelperronense. Entre las piezas talladas en tal materia prima existe un fragmento mesial de lámina adelgazada con dorso, y una lasca laminar apuntada de talla delicada que describimos como una punta de Chatelperron atípica en nuestras primeras publicaciones ${ }^{5}$. Hay también una pieza apuntada de laterales convexos con retoque profundo en su zona meso-distal y extremo proximal cortical; un buril sobre lasca laminar espesa con huellas de reavivado; un pequeño raspador sobre lasca corta con frente lamelar pequeño bien formalizado; y una excelente raedera tallada en una lasca ancha y espesa. El repertorio se completa con varias lascas de cuarcita con retoques de distinto signo.

Las lascas en cuarcita forman el componente mayoritario en el pequeño repertorio industrial del nivel 2. El relativo equilibrio entre sílex y cuarcita registrado en el nivel 1 deja paso en este otro al dominio absoluto de útiles tallados en cuarcitas grisáceas de grano medio. El repertorio se limita a media docena de piezas de pequeña categoría, talladas en su mayoría sobre lascas de medio y pequeño formato, con retoques simples, ocasionales o discontinuos. Existen dos piezas con frentes retocados de manera nítida y continua, formando muescas o denticulaciones, que podrian asimilarse sutilmente a raederas someras.

Los componentes líticos del nivel 1 responden más bien a una industria chatelperronense que a un "musteriense con puntas de Chatelperron" (esta es la propuesta emitida por Maroto et alii, 2005: 107; Vaquero et alii, 2006: 424). En el nivel 2 predominan sin embargo útiles sencillos (muescas y denticulados) labrados en cuarcita, que corroboran una industria más arcaica. Teniendo en cuenta que estos dos niveles constituyen la misma unidad estratigráfica (hemos de recordar la presencia de remontajes) no tenemos más remedio que pensar nuevamente en un chatelperronense para el nivel 2.

\subsection{Limos, arcillas y derrubios estériles}

Bajo el tramo chatelperronense reposa una nueva unidad estratigráfica que se caracteriza por la mínima presencia de restos culturales. En este tramo casi estéril los exiguos materiales proceden de arrastres ocasionales y no revelan una atribución industrial precisa. En realidad nos hallamos con unos $45 \mathrm{~cm}$ de bloques y algunos lentejones limosos, que separar nítidamente los tramos chatelperronense y auriñaciense.

\section{Nivel 3:}

En contacto directo con el nivel 2 se halla una delgada capa de limos estériles, que hemos denominado nivel 3a. Presenta solo $5 \mathrm{~cm}$ de espesor medio en los cuadros 12 e 13 (en algunos puntos localizados alcanza incluso $10 \mathrm{~cm}$ ). En la transición hacia los cuadros $\mathrm{J} 2$ y J3 adelgaza de manera sustancial hasta desaparecer en los sectores más profundos de la covacha. La capa presenta un buzamiento SO-NE típico del depósito $D$ interior, con una caída muy discreta hacia el fondo del karst. Teniendo en cuenta la escasa potencia del nivel y su reducida generalización en planta, podríamos interpretar este nivel limoso como un pequeño evento de inundación muy localizado.

La débil capa limosa anterior cubre parcialmente un horizonte compacto de bloques calizos que constituye el nivel 3b. En este depósito se acumulan bloques de dimensiones relativamente variables: proliferan ejemplares de dimensiones grandes $(40-20 \mathrm{~cm})$, entre un amasijo de clastos de menores proporciones $(20-10 \mathrm{~cm})$. La imagen resultante es de un horizonte caótico de clastos, disperso de modo generalizado por casi toda la planta de la covacha. La disposición de los clastos certifica una solifluxión de los derrubios desde la repisa del exterior: hay un buzamiento discreto SO-NE, una pendiente modesta en los cuadros 12 e 13 , y una pendiente brusca en los cuadros $\mathrm{J} 2$ y J3. El resultado es una acumulación caótica de $30 \mathrm{~cm}$, que alcanza los $40 \mathrm{~cm}$ en los sectores más cercanos al arco de la visera y se adelgaza hacia los sectores más profundos. La interpretación más convincente pasa por concebir este nivel como la cuña final de un cono de derrubios procedente de la repisa exterior, que penetra hacia el interior de la covacha a modo de abanico. Entre este amasijo se insertó una matriz de arcillas marrones rojizas oscuras. En la matriz aparecieron tan solo cuatro lascas retocadas, dos de ellas con muescas, pero nada representativas para poder siquiera arriesgar una atribución industrial.

\section{Nivel 4:}

Bajo la capa de derrubios reposa sobre una capa de unos $20 \mathrm{~cm}$ de espesor que constituye el nivel 4 . Se trata de un relleno de arcillas y limos pulverulentos, de un color marrón claro, que contrasta con la tónica generalizada del relleno gravitacional de la covacha. Todo apunta a un evento de se-

(5) En realidad esta última pieza no tiene una silueta rectilinea nitida en el lateral opuesto al dorso. En su lugar, presenta dos laterales convexos retocados: hacia el lateral derecho posee un retoque de tipo semiabrupto, continuo y directo; hacia el lateral izquierdo tiene un retoque similar pero menos consistente y más limitado pues se concentra en su extremo distal. 
dimentación local, que se depositó en posición casi horizontal. En el nivel se identificaron únicamente un par de raederas. La más significativa está tallada a partir de una lasca de sílex amarillento (muy habitual en la región), con un retoque elaborado, continuo y directo tanto en el lateral izquierdo (convexo) como en el derecho (recto).

\subsection{El Auriñaciense}

Bajo el tramo estéril anterior aparecen dos niveles con unos rasgos industriales prácticamente idénticos y una filiación auriñaciense clara. Estos niveles forman el tramo intermedio de la columna estratigráfica, tramo que alcanza hasta el medio metro de espesor. Los dos niveles auriñacienses tienen una mayor representación en planta que los chatelperronsenses, pero comparten con ellos un marco sedimentario y estratigráfico similar: sedimentación masiva, aportes gravitacionales desde la repisa exterior y procesos de removilización detectados desde los niveles superficiales.

\section{Nivel 5:}

Bajo las arcillas y los limos del nivel 4 aparece una nueva acumulación anárquica de bloques calizos. Los clastos de grandes dimensiones $(40-20 \mathrm{~cm})$ son el componente más característico del nivel si bien no son infrecuentes los que presentan dimensiones medianas $(20-10 \mathrm{~cm})$. No se trata de una capa homogénea, compacta y sólida de clastos. Ni comporta una acumulación generalizada de derrubios por la totalidad de la planta interior. Tampoco es un horizonte muy potente para su composición clástica: la potencia media del nivel es de unos $20 \mathrm{~cm}$, resultando mucho más espeso en los sectores más cercanos a la repisa exterior, y adelgazando gradualmente conforme se avanza hacia el fondo de la covacha. El nivel presenta una pendiente discreta en dirección SO-NE, que coincide con el buzamiento generalizado del depósito hacia el interior del karst. La matriz que rellena los intersticios entre los bloques presenta una impronta arcillosa pulverulenta de color marrón clara rojizo. En las cotas superiores aparecen algunos pocos cantos rodados, que responden a una caída de materiales desde la repisa.

\section{Nivel 6:}

Los bloques calizos anteriores sellan un depósito relativamente potente, una masiva acumulación arcillosa con cierto componente arenoso y una tonalidad marrón rojiza (relativamente similar a la matriz arcillosa del nivel precedente, algo más oscurecida). El nivel se caracteriza por la reducida proporción de clastos calizos: prácticamente no hay bloques de gran tamaño ni tampoco rastro de bloques de tamaño medio, de manera que la presencia de clastos se reduce a los componentes de menor tamaño $(>5 \mathrm{~cm})$, esparcidos de manera más o menos ocasional por toda la planta de exca- vación. Pero esta reducida proporción de la fracción gruesa contrasta con la potencia media del nivel, que representa el depósito más espeso de los que hemos descubierto hasta el momento en la zona $D$ interior. El relleno de arcillas alcanza los $30 \mathrm{~cm}$ de potencia media, alcanzando incluso los $40 \mathrm{~cm}$ en los sectores del cuadro 12 más próximos al arco de la visera. El espesor del nivel adelgaza paulatinamente a medida que nos internamos en el karst, sobre todo hacia los cuadros $\mathrm{J} 2$ y J3, hasta su desaparición en los sectores profundos de la covacha. Esta potencia tan variable guarda relación con el buzamiento. El nivel se depositó en subhorizontal en los cuadros 12 e 13, presentando una pendiente muy discreta en la dirección SO-NE que marca la caída general de todo el reIleno hacia el fondo del karst. Pero la pendiente se quiebra repentinamente a mitad de los cuadros $\mathrm{J} 2$ y J3 y se precipita profundamente hacia lo más profundo de la covacha, anticipando su desaparición a unos centímetros de la pared caliza.

Las arcillas del nivel cubren una planta útil todavía muy limitada: en torno a $4 \mathrm{~m}^{2}$, no muy representativa pero algo más amplia que la evaluada para el chatelperronense. En este cálculo hemos prescindido de los sectores periféricos que presentan todavía los inconvenientes derivados de los conocidos procesos de removilización. Por una parte, en algunos sectores del cuadro 13 resultan perceptibles los nocivos efectos originados por la penetración de las raíces exteriores en su camino hacia el interior del karst. Por otra parte, en algunos de los sectores de los cuadros 12 y J2 más próximos al arco de la visera, aun se aprecia el canal de escorrentía que penetra desde la repisa exterior, alcanzando en tal punto una anchura de $15 \mathrm{~cm}$. Pero conviene tener presente que las cicatrices erosivas de ambos procesos siguen siendo nítidas, por lo que hemos podido aislar sin impedimentos los limites de las perturbaciones, discernir con claridad los sedimentos indemnes y seleccionar los restos culturales procedentes de sedimentos intactos.

Los dos niveles han conservado una proporción de restos bastante reducida. El pequeño muestrario industrial desde luego no proporciona una base oportuna para el análisis estadistico. Pero por fortuna posee las piezas necesarias para realizar un diagnóstico cultural categórico. Tales materiales proceden de aquellos sectores con las mejores garantías estratigráficas: particularmente en el cuadro 12 y en menor medida J2. Pues a medida que nos internamos hacia el fondo de la covacha se aprecia un retroceso gradual de la densidad de restos, que acaba por convertir los sectores más profundos en un área prácticamente casi estéril y marginal. El nivel 5 resume los rasgos principales que caracterizan al repertorio instrumental de esta unidad: una proporción bastante equilibrada entre cuarcita y silex; una presencia consistente de piezas laminares; y sobre todo la aparición de piezas auriñacienses convencionales. 
Entre los útiles más reveladores resaltan tres piezas: un delicado raspador plano en hocico sobre lámina retocada (con rotura proximal), tallado en una variedad de sílex beige habitual en la región; un fragmento proximal de lámina, con sus laterales cubiertos por retoques auriñaciense (el derecho marcando una muesca); y un raspador atípico de frente corto y muy abrupto. Las últimas dos piezas presentan la superficie profundamente alterada por las huellas típicas de combustión, que ha sustituido la tonalidad original por una coloración intensamente enrojecida. Entre las restantes piezas de sílex hallamos un ejemplar de raspador-buril, tallado en una variedad habitual de silex amarillento; y una lasca triangular tosca en sílex grisáceo con un par de retoques marginales.

La impronta auriñaciense de este tramo está avalada también por la presencia de piezas convencionales de industria ósea. En los sectores intactos de la planta se halló un pequeño fragmento distal de azagaya, de $2.5 \mathrm{~cm}$ de longitud, con una sección circular muy amplia; junto a restos pequeños de punzones tanto de sección oval como de sección aplanada. La industria ósea auriñaciense es más relevante si cabe en el nivel 6. En sus arcillas ha aparecido un repertorio de útiles reducido pero lo bastante diagnóstico como para apuntalar la impronta industrial (la mayoría del cuadro 12). Destacan un fragmento mesial de azagaya de sección aplanada; un punzón sobre diáfisis; y sobre todo un silbato realizado sobre falange, con la oportuna perforación intencionada circular. La industria lítica del nivel 6 es más pobre: podemos destacar un ejemplar de raspador sobre lasca ancha y corta, con un frente amplio y limitado por dos pequeñas muescas en cada extremo, que le aproxima a los raspadores en hocico de carácter atípico.

\subsection{El Musteriense}

El último tramo que hemos exhumado hasta ahora en el relleno de la zona $\mathrm{D}$ interior comprende tres niveles muy distintos pero relacionados por una historia sedimentaria de una particular trascendencia para conocer los orígenes de la ocupación musteriense final del yacimiento. Hay que tener en cuenta que esta historia sólo se puede entender en toda su extensión, recurriendo a la estratigrafía que se registra en la terraza, en la zona D exterior. Porque estos tres niveles son en realidad la prolongación al interior del karst de niveles reconocibles en la secuencia del exterior. De tal manera que el nivel 7 no es más que el tramo final de un imponente derrumbe que como veremos cubrió por completo la planta de la zona D exterior. Mientras que los niveles 8 y 9 son probablemente retazos de la ocupación musteriense que se registra en esa misma planta y que es la principal muestra de habitación excavada por ahora en esta zona del yacimiento. Pero antes de establecer estas oportunas concordancias estratigráficas, veamos cuales son las características especifi- cas de esos tres niveles tal como se exhumaron en la covacha o zona D interior.

\section{Nivel 7:}

El nivel 7 representa un nuevo horizonte gravitacional con un carácter crioclástico, una agrupación de clastos calizos depositados de manera caótica sobre parte de la covacha. La mejor representación de este nivel se halla en parte de los sectores más externos de los cuadros 12 e 13 , los que se sitúan bajo el arco de la visera caliza actual y por tanto los que conectan con la zona exterior y la repisa. La imagen en planta que se registra en estos sectores muestra una concentración densa de gelifractos, que ronda los $35 \mathrm{~cm}$ de potencia y presenta una relativa consistencia. En esa capa hay una representación notable de gelifractos de dimensiones en torno a $20-30 \mathrm{~cm}$ y presencia complementaria de gelifractos de menor tamaño $(10 \mathrm{~cm})$.

Lo más peculiar de este cúmulo de clastos es su pérdida de consistencia a medida que progresamos hacia el fondo de la covacha. En el centro de la misma el nivel resulta ya muy poco consistente: la trama pierde solidez y potencia hasta tal punto de que se ha convertido solo en una pequeña capa de clastos, ya bastante dispersos, con un retroceso de los componentes medianos a favor de los elementos más pequeños. La pérdida de consistencia no es más que un adelanto de la desaparición del nivel, que se convierte en una realidad hacia el primer tercio de los cuadros J2 y J3. En estos lugares profundos de la covacha no hay clasto alguno, y en su lugar aparece una capa de arcillas poco consistente y pulverulenta.

Las características del depósito, la disposición de clastos en altura y su distribución en planta no dejan lugar a duda sobre la génesis de este nivel. Nos hallamos simplemente ante la muestra final de un horizonte de derrumbe que se desliza desde la zona D exterior hacia la covacha, la cuña terminal de un cono de deyección (solifluxión) que arrastró hacia el karst interior los restos de un derrubio crioclástico procedente de la terraza. Pero la intensidad de la caída no resultó suficiente como para cubrir la totalidad de la planta de la zona D interior y así los clastos no se desplazaron hasta los tramos más profundos. Ni tampoco contó con la energía suficiente para transformar la disposición original del nivel subyacente (8), que de esta manera cuenta con una preservación excepcional.

La matriz que cubre los intersticios entre clastos procede de la masa arcillosa del nivel precedente (6): dicho de otra manera, el proceso de derrumbe no arrastró aportes finos, que proceden de la sedimentación posterior. Esta génesis revela la procedencia cultural de los restos industriales del nivel, cuyo repertorio instrumental se limita únicamente a un par de raederas en cuarcita. La matriz de relleno son unas arcillas de color marrón oscuro rojizo, más plásticas en los cuadros 12 e 13, pero levemente pulverulentas en los cua- 
dros J2 y J3 (posiblemente en relación con la pérdida de humedad en los sectores internos del kasrt). En cualquier caso tan pequeños matices no alteran la homogeneidad interna del nivel, que aparece como una unidad clara. El único matiz relevante es la presencia de ciertos elementos de carácter fluvial en el techo del cuadro 12, unos pocos cantos rodados y una serie de lentejones de arenas estériles de pequeña potencia y amplitud muy limitada.

La profundidad del nivel 7 ha impedido la intervención tan perniciosa de aquellos procesos de bioturbación que en los niveles precedentes habían desmantelado parte de la periferia. Este el primer nivel de la zona D interior que no aparece parcialmente revuelto por la erosión múltiple que originaron las raíces exteriores, madrigueras y canales de escorrentía. Esta inmunidad viene motivada por estas dos razones. En primer lugar, porque las cotas del nivel son lo bastante profundas para impedir la acción erosiva de las raíces exteriores. En segundo lugar, porque la compacta capa enlosada que formaron los clastos y bloques impidió la excavación de madrigueras de animales. En realidad la compacta masa de bloques del nivel 7 acabó siendo una base sólida para el pozo de la madriguera y, ya de paso, aseguró la preservación de los niveles siguientes.

Pero en aquellas zonas desprotegidas por la masiva capa de bloques calizos (en lugares profundos de la covacha) hemos registrado procesos de perturbación diagenética. La imagen en planta a la cota del nivel 7 (fig. 7) permite reconocer los pequeños pozos de removilización debidos a la excavación de madrigueras animales, justamente en aquellos puntos desprotegidos por la masa compacta de los bloques. El primero está ubicado entre los cuadros 12 e 13 y en realidad no es más que la prolongación terminal de la amplia red de madrigueras que destrozó la conexión de las zonas $D$ interior/exterior. El segundo pozo se localiza en la periferia más profunda de la covacha (cuadro J3): es una hondonada ovalada de $40 \times 20 \mathrm{~cm}$, con unos límites claros y perfectamente discernibles, que desmanteló parte de la matriz pulverulenta periférica.

Los materiales culturales que se han hallado entre la capa de clastos son mínimos y responden a su arrastre 0 caída desde las zonas situadas más allá de la visera actual, en concreto desde la terraza de la zona $\mathrm{D}$ exterior.

\section{Nivel 8:}

El nivel 8 representa un importante cambio de tendencia en las pautas de sedimentación del relleno de la zona D interior. La trascendencia cronoestratigráfica -industrial del nuevo nivel se resume en tres ideas. En primer lugar, su régimen de sedimentación se distancia netamente de las constantes de sedimentación masiva por coluvión que han caracterizado los niveles anteriores, mostrando patrones de deposición cultural intacta. En segundo lugar, sustenta un salto cronológico respecto de los niveles precedentes al pro- porcionar un repertorio industrial musteriense datado según las dataciones radiocarbónicas en un Musteriense pleno. En tercer lugar, presenta una representación más o menos fidedigna de la principal unidad de ocupación de la zona $D$ exterior (nivel 4b-4a).

El nivel comprende $10 \mathrm{~cm}$ de arcillas de un color marrón y una textura relativamente pulverulenta. Hemos registrado pequeñas variaciones en la tonalidad de la matriz, que se encadenan con la intervención de procesos sedimentarios y con los índices de habitación. La matriz de los cuadros que componen la banda J ostenta una coloración clara, coincidiendo con un empobrecimiento tanto de la materia orgánica como de la producción cultural. Por el contrario, en los cuadros de la banda I, la matriz posee un tono más oscuro que armoniza con un mayor contenido orgánico y riqueza arqueológica. Los puntos más oscuros aparecen en algunos sectores del cuadro I2, que exhiben pequeños parches de tonalidad marrón negruzca.

El nivel no cuenta con clastos calizos de gran tamaño. No hay más que unos pocos clastos de medianas y pequeñas dimensiones (10-15 cm), que aparecen dispersos sin un orden aparente, sin una pauta definida. La totalidad de los clastos aparecen depositados horizontalmente (rasgo extensible a huesos y piezas industriales), que contrasta con la deriva registrada en los buzamientos de los niveles anteriores de la secuencia. Esta horizontalidad revela unas condiciones de sedimentación peculiares que aumentan de ahora en adelante en íntima relación con el incremento de la intervención antrópica.

En términos generales, las huellas de actividad humana del nivel son todavía relativamente discretas (fig. 5). El repertorio industrial es más numeroso que el registrado en cualquier nivel anterior de la covacha, pero todavía muy distante de una producción arqueológica intensa. Hemos recuperado una cantidad discreta de huesos, una variedad limitada de restos de talla y una colección restringida de útiles, que revelan unas condiciones modestas de habitación. Dentro de estos parámetros resulta no obstante muy interesante la presencia de una tendencia gradual de incremento de la riqueza arqueológica del techo a la base del nivel. Esta progresión representa una paulatina intensificación de la actividad humana, que a decir verdad forma parte de una tendencia de mayor alcance pues alcanza también al nivel 9. Estas son las pautas de intensificación que hemos detectado a lo largo del nivel:

- Tramo transicional. En el tramo superior del nivel, que reposa justo por debajo de la capa homogénea de gelifractos (nivel 7), la proporción de restos culturales es bastante discreta. No hemos reconocido ninguna pauta de concentración de materiales, pero sí hemos apreciado una modesta acumulación de cantos de arenisca de tamaño medio $(10-15 \mathrm{~cm})$, localizada en 
Planta de distribución de materiales arqueológicos: Nivel 8 interior.

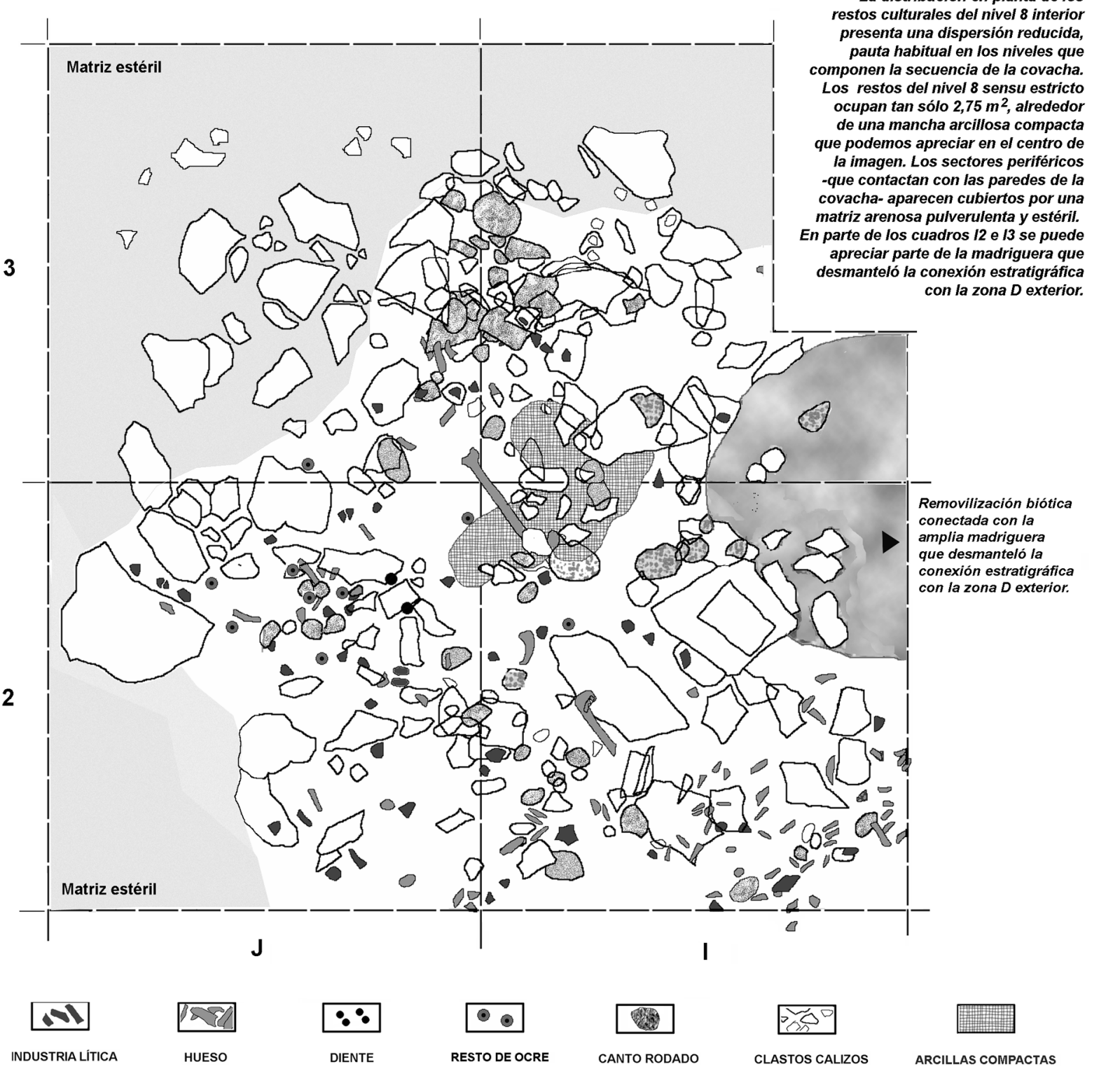

A Figura 5. Planimetría del nivel 8 interior.

los sectores centrales de la covacha. Entre algunas de las areniscas todavía quedan los rastros del nivel anterior, pequeños clastos calizos que no son más que los últimos retazos del derrumbe del nivel 7 .

- Tramo medio. En las cotas medias del nivel se detecta un aumento modesto pero representativo de la producción de restos arqueológicos. Ese incremento es parejo con un tenue oscurecimiento de la matriz arcillosa y desaparición de los bloques calizos. Prueba de la clara continuidad con el tramo superior ya descrito es la presencia de cantos de arenisca, depositados por la mayoría de la planta interior sin pautas nítidas de concentración. No obstante, hemos registrado reta- zos muy sutiles de un cambio de tendencia en las pautas de distribución de restos. En la zona central de la covacha hemos identificado una mancha arcillosa relativamente compacta, de un color ceniciento levemente rojizo, de trazo irregular y límites algo difusos. La mancha presenta unas dimensiones importantes pues alcanza los $30 \times 45 \mathrm{~cm}$. En su interior no se han reconocido restos y en el entorno tampoco hay muchos materiales: sólo algunos restos óseos, un par de pequeños cantos de arenisca y un par de lascas de cuarcita. Teniendo en cuenta la textura y tonalidad de ese lentejón podriamos estar ante las huellas leves de procesos de rubefacción, en un marco difuso de 
ocupación que en principio no parece muy trascendente si bien resulta harto relevante como muestra de un proceso de antropización del depósito que aumentará con la profundidad.

- Tramo inferior. En la base del nivel (podríamos decir que en un marco transicional hacia el nivel 9) registramos un nuevo incremento de la riqueza arqueológica. El aumento generalizado de los huesos, restos de talla y útiles viene a ser un paso más en la creciente antropización que registra esta unidad de techo a base. Es un marco todavía difuso porque no aparecen estructuras formales, pero en el que se advierten pautas peculiares en la dispersión de restos. La primera consiste en una acumulación de cantos de arenisca en los sectores centrales de la covacha, que alcanza unas dimensiones de $40 \times 40 \mathrm{~cm}$. La segunda es una relativa asociación de pequeños restos de ocre hacia el interior del karst, que presenta una dispersión de $40 \times 20 \mathrm{~cm}$. La preservación de las pautas de distribución coincide con la mejoría en la conservación de los restos, tal como se evidencia del buen estado que presenta alguno de los restos óseos, coincidiendo con una deposición claramente horizontal. En algunos sectores centrales de la covacha incluso se han recuperado ejemplares de huesos largos casi integros y completos a pesar de la fragilidad que se desprende de su estrecha sección transversal.

El nivel reviste una planta útil próxima a los $2,75 \mathrm{~m}^{2}$, si bien la mayoría de los restos se concentran en torno a los sectores centrales de la covacha. Desde los sectores centrales, la riqueza material retrocede de modo gradual hacia la periferia que limita con las paredes calizas (cubierta por una matriz ya pulverizada y arenosa). Esta distribución radial obedece a una pauta cultural de aprovechamiento del espacio que se repite en el nivel siguiente. En estos sectores periféricos más profundos la actividad antrópica desaparece a favor de procesos de removilización animal. La huella visible de estos procesos es la existencia de un pozo ovalado en los sectores del cuadro H3 más internos, que lindan con la pared y descienden hacia el cono de deyección. Se trata de una depresión ovalada de $50 \times 85 \mathrm{~cm}$ de extensión, que penetra los $10 \mathrm{~cm}$ del nivel, relleno de las arenas sueltas, pulverulentas y estériles propias de revueltos, limitado por una cicatriz muy clara y nítida. El pozo representa una pequeña madriguera que socavó las zonas marginales del nivel, sin contenido cultural alguno.

El nivel 8 ha proporcionado numerosos fragmentos óseos y restos de talla pero el repertorio instrumental lítico es muy reducido. De hecho, la pieza más relevante es una punta levallois típica que al menos permite una asignación clara, marcando la ruptura con los niveles culturales anteriores y permitiendo su enlace con el nivel posterior 9 .
La situación periférica de la madriguera anterior coincide con la primera comunicación con el tramo superior del cono de deyección que detectamos desde la sala interior de la cueva. La restauración de la comunicación con esta sala se registra a la altura de este nivel 8 , a través de una pequeña hendidura de unos $20 \mathrm{~cm}$, libre de sedimentos, enmarcada junto a las paredes calizas (cuadros K2-K3). Este agujero presenta una capa superficial arenosa muy pulverulenta, semejante a la que cubre el cono de deyección interior. La hendidura permite contemplar una pendiente de unos 4-5 m de potencia y corrobora por tanto la existencia de un importante depósito arqueológico.

Nivel 9:

Los primeros rastros difusos de actividad antrópica in situ detectados en el nivel 8 no son más que la antesala de la rotunda imagen representada por el nivel 9. Las arcillas de este nivel conservan los testimonios de habitación más importantes de todos los reconocibles en la dilatada secuencia estratigráfica de la covacha. La impronta antrópica del nivel 9 reposa en estos tres rasgos: la impresión intensa de restos de combustión; la presencia de un repertorio limitado pero muy distintivo de restos industriales; y finalmente la detección de unos patrones inequívocos de organización espacial. Desde el punto de vista industrial el nivel 9 representa un punto de inflexión no menos relevante: la presencia de una serie de piezas líticas bastante delicadas de impronta levallois nos sitúa en tiempos musterienses. El nivel se halla todavía en proceso de excavación, pero los datos recogidos permiten restituir una imagen muy clara de su composición.

Hasta el momento hemos profundizado unos $10 \mathrm{~cm}$ (que no responde a su potencia íntegra porque no se alcanzó la base). El nivel se caracteriza por una matriz arcillosa relativamente suelta, que incorpora cierto componente de arena en algunos puntos periféricos. La presencia mínima y esporádica de clastos calizos (de pequeño tamaño) nos sitúa ante un marco muy distinto al registrado en niveles precedentes. Las arcillas poseen una tonalidad marrón intensa, que se oscurece alli donde se registran concentraciones de materia orgánica y restos de carbón. En realidad hemos detectado una evolución interna en la matriz a medida que progresamos en profundidad, a partir de las siguientes tendencias: un oscurecimiento paulatino del sedimento, una compactación progresiva de las arcillas, un enriquecimiento continuado del contenido carbonoso y un aumento gradual de los restos arqueológicos. Esta progresión toma cuerpo en un patrón de estratificación horizontal representativo de una deposición intacta.

Dentro de esta evolución, a unos $5 \mathrm{~cm}$ del techo del nivel, entre unas arcillas arenosas muy oscurecidas, aparecen nitidamente dos acumulaciones a manera de lentejones, intensamente ennegrecidos por la alta concentración de restos de carbón. En principio los límites resultan levemente difu- 
minados, pero podemos determinar con claridad la morfología y las dimensiones. El primero consiste en un lentejón circular de 15-20 cm de diámetro y unos $3 \mathrm{~cm}$ de espesor, una tonalidad negruzca intensa bastante homogénea y contornos compactos. La segunda mancha posee dimensiones mayores: ronda $35-40 \mathrm{~cm}$ de diámetro y posee $5 \mathrm{~cm}$ de espesor. Presenta unos contornos más difusos y una coloración interna mucho más heterogénea. Hay un área central mucho más compacta e intensamente oscurecida; y un área periférica que pierde paulatinamente compactación y modera la tonalidad negruzca, para ganar en pulverulencia y asumir una gama roja intensa. En la banda perimetral del lentejón la masa arcillosa presenta una textura más arenosa y una tonalidad rojiza, probable representación de una orla de materia rubefactada.

La planimetría de los lentejones no dejan lugar a duda: se hallan emplazados en un área concreta de la covacha, en los tres sectores del cuadro 12 situados justo bajo el arco de la visera occidental, por tanto colindando con la repisa al aire libre. El perfil estratigráfico para los cuadros J2 y J1 permite reconocer con bastante exactitud la localización de estas manchas negruzcas (fig. 4), y apreciar cómo se prolongan hacia la repisa exterior, que permanece todavía sin excavar.

Pero el horizonte carbonoso del nivel 9 se amplía también hacia puntos más internos de la covacha (representados por los cuadros 13 y J3). En esos sectores no se detectan lentejones oscuros pero sí una acumulación densa, tupida y amplia de pequeños residuos de carbón/cenizas. Es tal el contenido carbonoso, que la matriz arcillosa presenta una coloración marrón ligeramente ennegrecida y posee numerosas huellas de carbones pulverizados. Hasta este momento hemos coordenado más de medio centenar de minúsculos puntos de carbón ( $>1 \mathrm{~mm}$ de diámetro) en un espacio limitado por ahora a tres sectores. Esta capa de restos ocupa un espesor de tan solo 1-2 cm y se sitúa a la misma cota que los lentejones del cuadro inmediato, por lo que podemos avalar la estricta deposición horizontal de todo este registro de combustión. Los restos de carbón aparecen distribuidos de manera regular pero siguiendo una pauta radial: hay una concentración mayor en los límites con los lentejones del cuadro 12, y un retroceso paulatino hacia el fondo de la covacha. Finalmente, entre las menudencias de carbón se haIlan pequeñas partículas de ocre ( $>1 \mathrm{~mm}$ de diámetro) de un color rojizo intenso.
Estos componentes permiten interpretar el nivel 9 como un horizonte de combustión. El marco está compuesto por dos franjas adyacentes: una franja central compuesta por los lentejones de carbones/cenizas que se concentran en los sectores inmediatos a la repisa; y una banda periférica de cenizas que se dispersa hacia el fondo de la covacha. Hasta ahora este complejo de combustión no parece tener relación con una estructura muy formalizada: por el momento no hemos reconocido estratificaciones en altura propias de un hogar complejo, ni acumulación de cantos, ni planificación estructurada del espacio. El marco excavado hasta el momento responde mucho mejor a una estructura difusa, con una pauta radial en la concentración de índices de carbón en planta. Existen unos pocos cantos de areniscas dispersos junto a los lentejones, de medianas dimensiones y superficies ennegrecidas de carbón.

En la actualidad (hasta la excavación del retazo del nivel conservado en la repisa), la interpretación más verosímil de esta estructura de combustión ${ }^{6}$ fluctúa entre estas dos hipótesis igualmente convincentes. La primera pasaria por asociar los lentejones centrales con un hogar plano más o menos desestructurado. La segunda permitiría interpretar los lentejones y la dispersión de cenizas complementaria como una deposición secundaria de restos de hogares a modo de una "estructura de evacuación" (Leroi-Gourhan, 1983: 239), una estructura de desecho o una especie de vaciado de hogares convencionales ${ }^{7}$. Desde tal punto de vista, el nivel 9 representaría básicamente un horizonte de abandono de los residuos de hogares dispuestos en otras zonas de la cueva: en tal caso la covacha albergaría un área de desescombro, un basurero marginal al fondo del abrigo, donde se acostumbraba a abandonar las cenizas y restos orgánicos consumidos en los hogares de la cueva. Los lentejones ubicados bajo el arco no serían más que el grueso de los desechos, y la dispersión de carbones colindante pasarian por ser los restos de las pavesas levantadas por el acto de arrojar los cenizales al suelo.

Entre los lentejones y las orlas rubefactadas del cuadro 12 se acumulaban restos óseos de pequeñas dimensiones, la mayoría fragmentos menores de $5 \mathrm{~cm}$, muy triturados, y pequeñas esquirlas de imposible identificación. Por regla general, poseen un estado de conservación muy precario, las superficies astilladas e intensamente teñidas por una tonalidad oscurecida con arcilla carbonosa. No son pocos los restos que muestran las trazas de combustión, si bien es difícil pensar por ahora en una utilización de los huesos como com-

${ }^{(6)}$ Para esta ocasión usamos el término estructura de combustión en el sentido genérico que aplicó André Leroi-Gourhan en su estudio de Pincevent, en sus propias palabras como "cualquier conjunto de restos que comporten elementos que han sufrido la acción del fuego» (Leroi-Gourhan, 1973: 4).

(7) En este caso concreto, entendemos como vaciado de hogar toda aquellas "acumulaciones que comportan sobre todo su espesor en una amalgama de partículas negras, grises y rojo-oscuro en las cuales se incluyen restos que han sufrido la acción del fuego y otros que están intactos" (Julien, 1983: 283-284). En cierto modo y salvando las distancias, este marco de cenizas intensas detectado en La Güelga nos remite a las superficies complejas halladas entre los niveles musterienses de El Castillo, que reunían junto a los hogares convencionales, capas de cenizas con sedimentos negros y grasientos en unos casos, violáceos en otros (Cabrera, 1984: 95-96). 
bustible según se propone en otros yacimientos musterienses (Yravedra et alii, 2005: 371-372). Hay que tener en cuenta que en los sectores excavados del cuadro 13 no hay restos óseos, justamente a la cota de la amplia dispersión de cenizas que podríamos interpretar como las pavesas del vaciado.

Entre las cenizas del cuadro 12 también se han recogido restos industriales. Intensamente teñidos por la materia oscura de los lentejones, hemos recogido un conjunto modesto pero interesante de útiles líticos. Lo llamativo de ese repertorio es su calidad tecnotipológica: buena parte de ellos revelan una refinada elaboración, exhiben un alto grado de habilidad técnica y avalan un interés por la talla de aquellas variedades de cuarcita más finas. Este repertorio cuenta con piezas bastante convencionales y muy estandarizadas: piezas con una factura excelente, talladas sobre lascas de medianas dimensiones, que aportan claras condiciones de adaptación ergonómica envidiables.

Las piezas más elaboradas formalmente son las raederas: suelen aparecer talladas en soportes espesos, por lo normal con lascas de dimensiones medianas; presentan retoques muy formalizados con cierta impronta escamosa; poseen a veces filos denticulados; y acusan en ciertos casos una impronta levallois característica ${ }^{8}$. Pero también hay ejemplares muy bien conseguidos de cuchillos de dorso, en particular de los elaborados sobre dorso natural. La imagen que desprende la colección resulta ciertamente sofisticada de tal manera que podiamos hallarnos ante un conjunto seleccionado de piezas de cuidada elaboración técnica y que exigen una notable inversión de trabajo.

La relevancia cultural de este nivel motivó la recogida de las oportunas muestras óseas para su envío al laboratorio de radiocronología. Para la toma de muestras se recurrió a los cuadros y sectores que ofrecian mejores garantías de preservación y se seleccionaron fragmentos óseos con mejor conservación frente a procesos de carbonatación y con trazas antrópicas de cara a avalar la génesis cultural. Los restos se confiaron a 0xford Radiocarbon Accelerator Unit (ORAU), que aplicó un protocolo de limpieza con las tareas oportunas de pretratamiento químico al objeto de garantizar la viabilidad de las muestras (Bronk Ramsey et alii, 2004; Bronk Ramsey, Higham y Leach, 2004). Los resultados han revolucionado la imagen que hasta el momento teníamos de la zona $\mathrm{D}$ interior al tiempo que permiten trazar hipótesis de lo más prometedoras en la reconstrucción cronoestratigráfica de todo el yacimiento (más detalles al respecto en Menéndez et alii, 2009: 206-209). La primera datación AMS ${ }^{14} \mathrm{C} /$ hueso del nivel 9 ha suministrado la fecha $43.700 \pm 800$ B.P. (OxA19244). La segunda datación $\mathrm{AMS}{ }^{14} \mathrm{C} /$ hueso ha revalidado esta posición cronológica pues ha facilitado la fecha 44.300 \pm 1.200 B.P. (0xA-19245). Estas fechas nos sitúan en un episodio avanzado del Paleolítico medio o "Musteriense pleno tardíon (previo a lo que se viene llamando Musteriense final).

\section{LA ZONA D EXTERIOR: LA SECUENCIA ESTRATIGRAFÍA E INDUSTRIAL}

Los trabajos realizados en la zona $D$ exterior revelan una secuencia de 1,80 $\mathrm{m}$ de potencia máxima hasta la base del nivel 4b. En el cuadro $\mathrm{G} 1$ realizamos un sondeo de mayor profundidad que alcanzó hasta los 2.50 metros, en la que se percibe un nivel arcilloso estéril que sirvió de base sedimentaria. La planta de excavación en esta zona ronda los $10 \mathrm{~m}^{2}$, una superficie limitada que imposibilita la comparación de unidades habitacionales pero que a la luz de los resultados permite conocer de manera solvente la geodinámica estratigráfica de la terraza $+9 / 11 \mathrm{~m}$. Hoy en día estamos en condiciones de asegurar que la planta de excavación proporciona las claves oportunas y necesarias para comprender la compleja historia sedimentaria que ha intervenido en la génesis y la evolución de la plataforma aterrazada, a la par que ha proporcionado una excelente muestra cultural para lo que es el nivel principal de ocupación (fig. 6).

La secuencia estratigráfica de la zona contiene tres grandes tramos (fig. 7). El primero consiste simplemente en un relleno de ladera, una masa arcillosa resultante de procesos de descomposición de calizas que integra tres niveles de génesis muy parecida. El segundo es un intenso episodio de crioclastia, una masa densa de bloques de caliza desprendidos de una antigua visera alzada sobre el lugar, que acabó cubriendo como si se tratara de un "enlosado", toda la planta de excavación. Y el tercero es el nivel de ocupación per se de la zona, que representa una intensa superficie de habitación datada en el Musteriense. Es un nivel que cuenta con una enorme acumulación de restos culturales, con un registro muy abundante, pero muy desbaratado por la inclemente caida de los grandes bloques de derrumbe del episodio de crioclastia que acabó con buena parte de la visera de la cueva.

\subsection{Los niveles de ladera}

Los tres primeros niveles que se suceden en la zona D exterior constituyen rellenos muy homogéneos de arcillas rojizas terrosas más o menos compactas y uniformes, que se suceden sin solución de continuidad. Estos rasgos son tan

${ }^{(8)}$ En el listado tipológico de los útiles recuperados en el nivel 9 que se han publicado con anterioridad (Menéndez, Garcia y Quesada, 2005, 2006), figura una lámina auriñaciense En realidad se trata de un ejemplar de raedera con un retoque continuo nitido y amplio en los dos laterales, que se enmarca perfectamente en el carácter musteriense del nivel. 


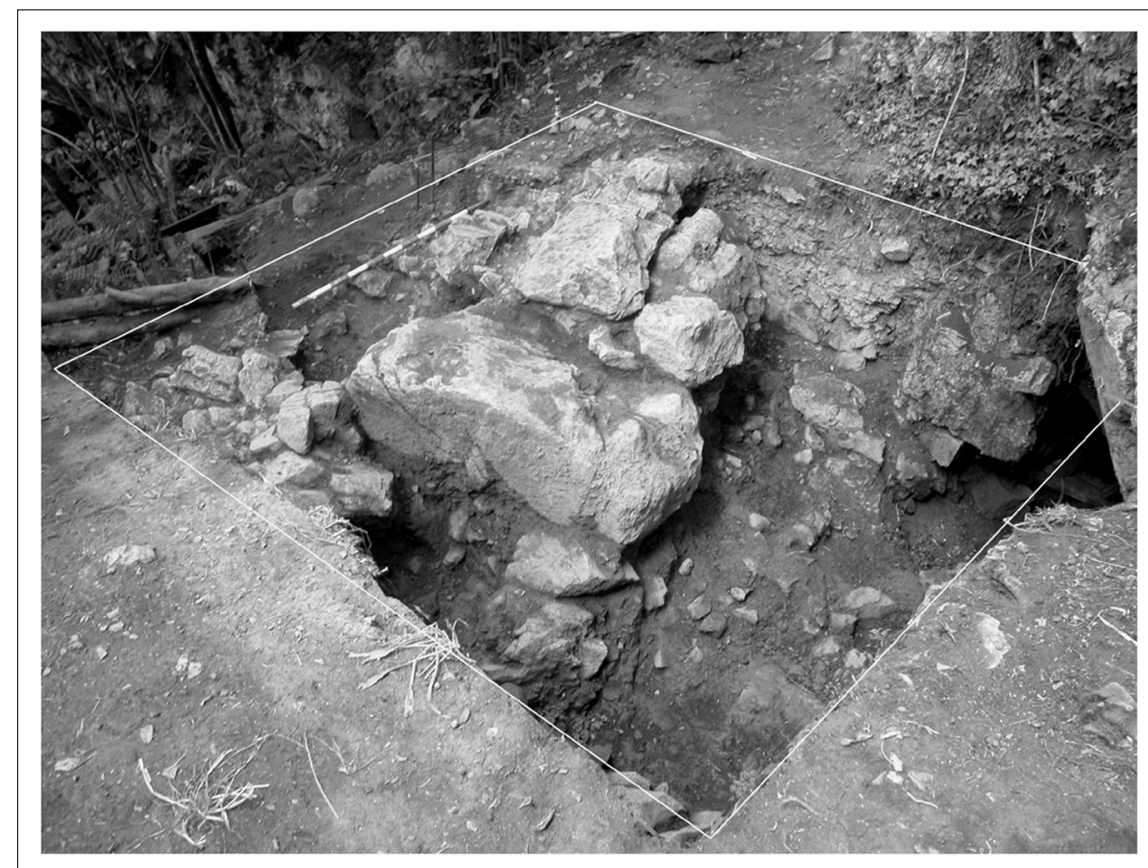

La planta de excavación de la zona $D$ exterior ocupa $10 \mathrm{~m} 2$, entre la pared caliza actual de la cueva y el talud de la ladera que vierte al cauce del arroyo de la Brava. Es una planta limitada pero que suministra todas las claves necesarias para la reconstrucción cronoestatigráfica.

En esta imagen podemos contemplar el proceso de excavación durante la campaña 2004. Se puede apreciar un retazo del nivel 3 en los cuadros próximos al talud (hacia la esquina superior izquierda). Asi como parte del techo del nivel 4 a en los cuadros más cercanos a la pared (esquina inferior derecha).

La masa de grandes bloques que ocupa el primer plano representa una de las fases del colapso gravitacional que provocó a la postre el desmoronamiento de gran parte dela visera caliza que se elevaba hacia el E (derecha de la imagen).

En el vértice superior derecho se puede ver la conexión con la zona $D$ interior o covacha. En ese punto se acumulaba el relleno de un

gran pozo revuelto, de una removilización relacionada con una amplia madriguera, que desmanteló por completo la conexión entre las dos zonas de excavación.

A Figura 6. Planta en proceso de excavación de la zona D exterior.

similares como para asegurar una génesis común que podemos relacionar con una acumulación de ladera a raíz de los convencionales procesos de arrastre de materiales desde cotas más elevadas de la terraza. Estas arcillas terrosas rojizas proceden de procesos de descomposición de la caliza, probablemente relacionados con los intensos procesos de desmantelamiento de la visera cuyos restos se elevan justamente por encima de la terraza.

\section{Nivel 1:}

Bajo una capa superficial de mínima potencia aparece el nivel 1. Es un depósito de arcillas de tonalidad marrón claro rojiza, que alcanza $20 \mathrm{~cm}$ de espesor medio, con el carácter compacto y homogéneo que se deriva de una sedimentación masiva. Presenta una cantidad moderada de bloques calizos; la mayoría de mediano tamaño $(10-20 \mathrm{~cm})$, si bien no faltan algunos ejemplares mayores $(30-40 \mathrm{~cm})$. Todos estos cantos aparecen dispersos de manera caótica, y depositados en las posiciones más dispares, tal como es previsible en condiciones de arrastre y caída de materiales. La presencia de cantos rodados en este nivel ajeno a procesos hidráulicos, presenta una nueva prueba sobre la naturaleza de arrastre. En realidad, el nivel 1 no es más que un típico relleno de ladera, provocado por la caída de materiales desde las cotas más elevadas de la plataforma aterrazada $+9 / 11 \mathrm{~m}$, que acabó por configurar la ladera actual de la terraza. El nivel presenta una potencia máxima de $20 \mathrm{~cm}$, en su cota superior, pero conforme se aproxima al talud actual de la ladera se acuña de manera paulatina. De tal manera que desaparece justo antes de la brusca caída del talud.
La presencia cultural es bastante reducida de manera que los materiales representativos se reducen a unos pocos restos de talla y útiles. El repertorio instrumental se limita a las lascas retocadas, algunas dotadas de retoque continuo por lo general denticulado, y otras con retoques simples que a lo sumo se podrian relacionar con raederas muy sencillas y de pequeño formato. En la superficie de muchas piezas aparecen pequeños retazos de costras, lo que revelan claramente la procedencia de arrastre del material.

\section{Nivel 2:}

No hay una ruptura estratigráfica nitida entre los niveles 1 y 2. En realidad, este segundo nivel posee una naturaleza sedimentaria similar a su precedente: un relleno arcilloso bastante homogéneo y compacto, de una tonalidad marrón rojiza, con clastos de mediano tamaño $(20 \mathrm{~cm})$ y más ocasionalmente bloques de grandes dimensiones $(40 \mathrm{~cm})$. El nivel reposa sobre la pared del abrigo pero hay un matiz interesante: penetra de una manera discreta hacia el interior del karst, más allá de la vertical exterior de la visera actual. Por tanto, participa de la acumulación de la ladera pero también interviene en la colmatación terminal de la antigua boca de la cueva. La potencia varía de una manera ostensible. En el perfil N-S el nivel progresa de manera gradual desde los 20 $\mathrm{cm}$ (cuadro G3) hasta $45 \mathrm{~cm}$ (E3), de manera que aumenta a medida que nos alejamos de la boca de la cueva. En el perfil E-O el nivel evoluciona de una manera paulatina pero mucho más drástica, pues progresa desde los $45 \mathrm{~cm}$ (E3) hasta $5 \mathrm{~cm}$ (E2), e incluso desaparece en el cuadro E1 por la erosión que ha sufrido la ladera próxima al talud. El material procede del 


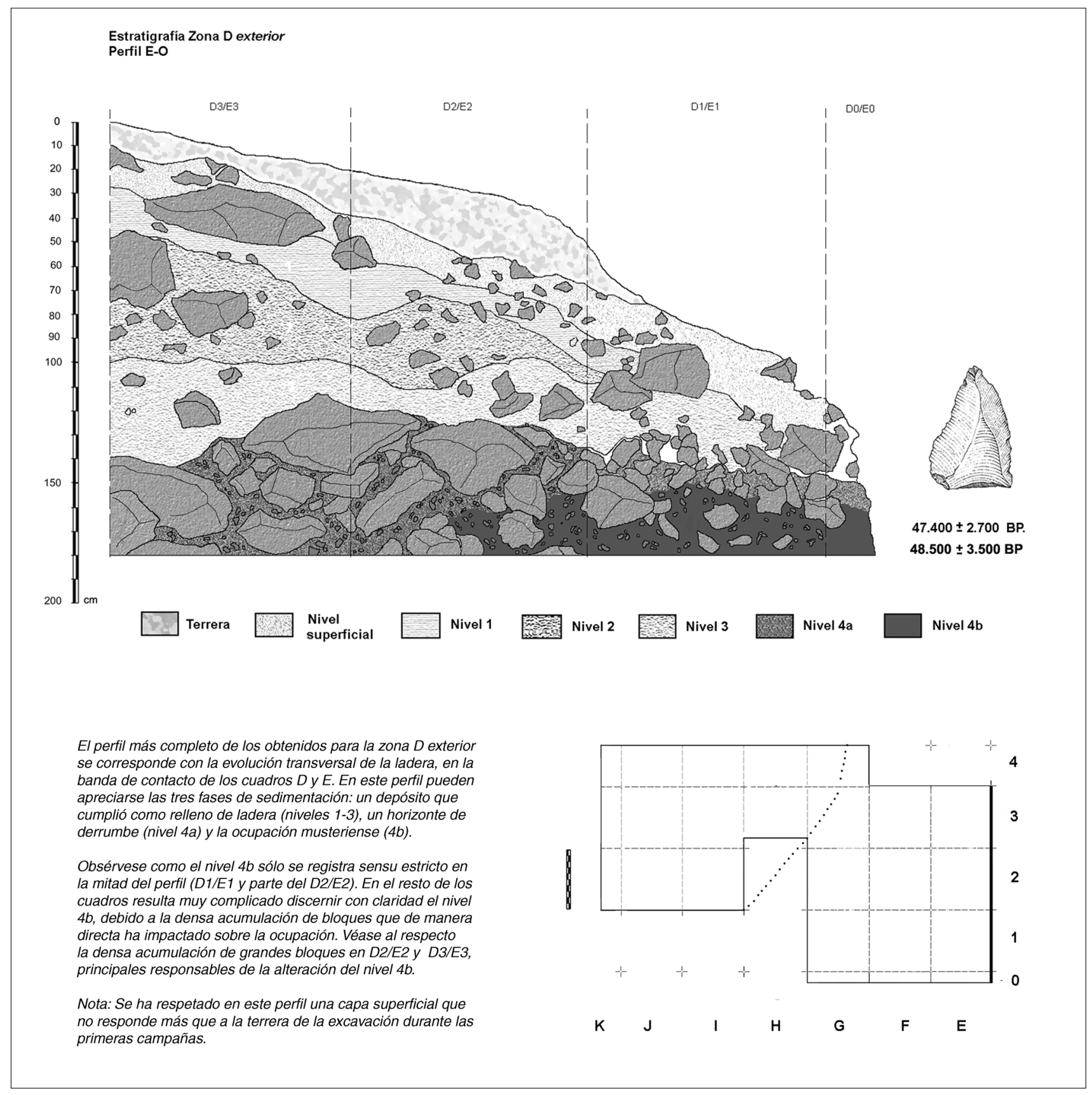

A FiguRa 7. Secuencia estratigráfica de la zona D exterior y dataciones ${ }^{14} \mathrm{C}$.

arrastre desde las cotas más elevadas de la terraza. La misma orientación de los pocos restos de fauna e industria confirma la deposición por caída o solifluxión. En este sentido la génesis del nivel 2 no es muy distinta de la prescrita para el nivel 1. De hecho, los criterios para discernir el tránsito entre ambos niveles pueden considerarse como meros matices: hay una mayor compactación del sedimento del nivel 2 y una tendencia leve hacia la horizontalidad en la base.

La naturaleza industrial del nivel es imprecisa por la penuria de los restos líticos y el carácter de arrastre del depósito. Hemos reunido más restos que el nivel anterior pero sigue siendo una colección insuficiente para proyectar in- terpretaciones más allá de una atribución industrial aproximada. Huesos fragmentados, productos de talla lítica de mediano tamaño, y útiles tallados sobre lascas de cuarcita de tamaño mediano, aparecen en un número relativamente modesto. El repertorio instrumental posee piezas muy reveladoras para la caracterización industrial del nivel. Hay una abundancia relativa de lascas de cuarcita siguiendo un patrón de trabajo: presentan un tamaño pequeño; formato subtriangular; base bastante espesa; laterales convergentes; retoques simples continuos; en ocasiones silueta levemente denticulada y en otras trazada con una simple muesca. Este tipo de piezas podrían interpretarse a lo sumo como raede- 
ras muy someras, y en cierta manera recuerdan las piezas de formato subtriangular reconocidas en los yacimientos de $\mathrm{El}$ Habario B (Carrión y Baena, 2005: 447) y El Esquilleu XVII (Baena et alii, 2005: 475). Buena parte de este repertorio industrial de La Güelga parece revelar unas prácticas relativamente oportunistas. En el capitulo de las raederas, los ejemplares que presentan mayor inversión técnica no pasan de ser pequeñas lascas de morfologías muy heterogéneas y retoques muy limitados en extensión. El mismo carácter oportunista se percibe en algunas lascas con retoques simples muy someros, y en muescas labradas sobre lascas de morfología casual, con trabajo de retoque muy superficial y limitado.

\section{Nivel 3:}

Nuevamente no hay una ruptura estratigráfica nítida entre los niveles 2 y 3. La transición hacia este último es gradual y paulatina, de tal modo que no se detecta cambio radical ni en la textura, ni en la tonalidad de la matriz, ni en la composición de los clastos. El nivel posee una naturaleza arcillosa y coloración marrón rojiza bastante homogénea, relacionada con un contexto de estratificación masiva. En comparación con el nivel precedente, este depósito presenta una matriz levemente más seca, más suelta, y una participación mayor del componente grueso. En su interior se dispersan clastos de medianas dimensiones $(10-20 \mathrm{~cm})$ de manera caótica, junto a clastos de mayor calibre $(30-40 \mathrm{~cm})$ en algunos puntos localizados de la planta. Hay una acumulación de grandes bloques realmente importante en los cuadros centrales (G2-G3), constituido por clastos de hasta 40-50 $\mathrm{cm}$ de largo, que representan procesos de desmantelamiento de la antigua visera caliza. El espesor reproducido en el perfil N-S presenta por término medio unos $35 \mathrm{~cm}$, con muy poca variación pues oscila entre los $40 \mathrm{~cm}$ y los $30 \mathrm{~cm}$ justo bajo la pared de la visera caliza. Hacia el perfil E-0 que marca la ladera, la potencia del nivel se mantiene en torno a los 30 $\mathrm{cm}$, desapareciendo en el cuadro D0 apenas a unos centímetros del pronunciado talud. En comparación con el nivel anterior, este nivel 3 resulta mucho más representativo y estable.

La riqueza arqueológica es bastante similar a la registrada en los niveles anteriores. Entre los materiales industriales abundan los productos de talla de cuarcita de un mediano formato, labrados en la variedad grisácea de grano medio más habitual en el yacimiento. La colección instrumental comprende tan solo una treintena de útiles, en su mayoria recuperados en los cuadros E3 y F3. Buena parte han sido recogidos en cotas profundas del nivel y presentan incluso una leve capa brechificada sobre la superficie, a pesar de no haber huellas de procesos de carbonatación entre las arcillas del nivel. Restos similares con capas brechificadas se hallan en el nivel siguiente (4a), lo que parece asegurar que buena parte de las piezas industriales y de los huesos del nivel 3 proceden de la inyección por removilización de sedimentos más antiguos o del desmantelamiento parcial en otras partes de la terraza del nivel $4 a$.

El utillaje del nivel ofrece un muestrario muy heterogéneo de lascas retocadas. Muchas de las lascas presentan una inversión limitada de trabajo, con huellas de retoque muy esporádicas y morfologías poco estandarizadas. También hay lascas retocadas espesas y robustas, talladas en una variedad de cuarcita inhabitual en el lugar, que presentan laterales retocados de manera sumaria pero continua, en ocasiones con muescas y denticulaciones amplias. Entre las lascas retocadas hay ejemplares de pequeño formato pero con un trabajo más habilidoso, con trazas de retoque más amplio y profundo, con un recorrido retocado mucho más extenso, con muescas y denticulaciones nítidas, que podrian interpretarse como raederas sumarias (realmente las raederas convencionales son excepcionales). Dentro del capítulo de piezas convencionales contamos con una serie de lascas de formato subtriangular, con sus laterales convergentes dotados de retoques consistentes continuos (muy similares a las reconocidas en el nivel 2). Pero quizá las piezas más reconocibles son una punta levallois de tamaño medio y una magnífica punta musteriense robusta, masiva, con retoques laterales. Las últimas piezas permiten reconocer una importante impronta musteroide en el nivel, aunque las caracteristicas del depósito impiden certificar una homogeneidad o integridad industrial estricta. En las cotas más elevadas se recuperaron algunas pocas piezas de sílex que parecen alejarse de aqueIla tónica musteroide: hay un cuchillo de dorso de gran formato en radiolario casi idéntico a otro ejemplar hallado en el nivel 2 ; y una pequeña lasquita con tendencia laminar fabricada en chert.

\section{Procesos de removilización del nivel 3:}

La descripción del primer tramo estratigráfico (niveles 1-3) de la zona $D$ exterior no puede terminar sin mencionar las caracteristicas de un proceso de removilización notorio de importantes dimensiones y relevantes repercusiones en la interpretación del yacimiento. En publicaciones anteriores dejamos breve constancia del suceso (Menéndez, García y Quesada, 2005: 599-600) pero sin revelar detalles sobre su dimensión, carácter, ni sobre las secuelas que arrastra en la interpretación correcta del yacimiento. Es la ocasión ahora para aportar los datos necesarios, valorando tanto la magnitud como la trascendencia de un pozo que arrasó por completo el nivel 3, en un punto sumamente crítico en la reconstrucción estratigráfica. Este pozo desmanteló una buena parte del contacto estratigráfico entre las zonas $D$ exterior y $\mathrm{D}$ interior, lo que ha dificultado notablemente la reconstrucción total de la secuencia. Por fortuna, en estos momentos nos hallamos en las mejores condiciones para aportar una explicación solvente de la compleja historia taxonómica que concurrió en este punto. 
El pozo aparece a la altura del techo del nivel 3 y consiste en una intensa crioturbación originada por la excavación de una madriguera amparada bajo el extraplomo actual de la visera. El pozo ha afectado a los cuadros $\mathrm{G} 3, \mathrm{H} 3, \mathrm{G} 4$ y H4, pero se aprecia incluso en la mitad del $\mathrm{H} 2$ y en ciertos sectores de los cuadros E3, 12 e 13. De manera que a grosso modo podemos evaluar la planta afectada en casi $5 \mathrm{~m}^{2}$. Estos cuadros se corresponden justamente con una zona superior del extraplomo calizo que a la sazón sirvió de protección para la transición entre las zonas $D$ exterior y $D$ interior. La removilización afecta a los perfiles longitudinales y complica de manera sensible la interpretación conjunta de las dos zonas.

La matriz del pozo está formada por una arenas claras de tonalidad amarillenta, pulverulentas y sueltas, con algunos bloques calizos de tamaño grande-medio depositados en posición caótica. Muchos de ellos no son más que clastos que se desprendieron de la visera caliza, cayendo sobre la planta principal al aire libre y rodando en pendiente hacia el interior del karst. En otros casos, tal como se ha registrado entre los cuadros $\mathrm{G} 3$ y $\mathrm{G} 4$, los bloques no son más que clastos desprendidos de la visera del abrigo situada justo encima del pozo (basta comprobar la cicatriz erosiva marcada en el techo, provocada por la acción erosiva de las raíces de árboles que horadan el karst).

La matriz pulverizada posee una profundidad máxima de $1.20 \mathrm{~m}$. La base del pozo descansa en el techo del nivel $4 \mathrm{~b}$ y presenta unas características peculiares: de hecho la base consiste en una pequeña capa de arena amarillenta pero más compactada, de apenas $2 \mathrm{~cm}$ de espesor. Probablemente se trata de una superficie de la madriguera, que compactó gracias a que cubria los grandes bloques que componen el nivel 4a en la zona del pozo. La compactación fue posible por la acción de la madriguera bajo un depósito grueso de bloques. En tal sentido, todo parece apuntar que la acción de esta madriguera pulverizó fácilmente la matriz arcillosa del nivel 3 , pero no pudo arrasar con la compacta masa de los bloques calizos del 4a. De este modo los cantos del 4a protegieron el importante depósito del nivel $4 b$.

En el relleno se han acumulado numerosos restos de industria y fragmentos de huesos de distintos tamaños y de diversas épocas pues junto a piezas con la pátina antigua hallamos otros de aspecto reciente. Entre los huesos aparecen animales carnivoros, lo que avala el uso de esta zona como la madriguera típica usada por pequeñas alimañas bajo la protección de una visera caliza.

Resulta necesario añadir que el pozo mostraba claras cicatrices erosivas, lo que ha permitido delimitar con la nitidez necesaria las áreas inmediatas intactas. En su frente norte, este pozo (madriguera) contacta con otra zona removilizada, con el tramo final de la penetración de raíces que horadan la zona D interior. En todo caso, hemos podido delimitar con precisión los sectores que aparecian indemnes en la covacha y seleccionar así el material válido para las interpretaciones culturales.

\subsection{El horizonte de derrumbe: Nivel $4 a$}

Bajo las arcillas rojizas del nivel 3 aparece un depósito contundente y masivo de bloques de caliza de distintos tamaños, que cubren la totalidad de la planta de trabajo. Este depósito ha sido denominado nivel $4 a$ y básicamente responde a una concentración cuantiosa, muy compacta y generalizada de gelifractos (fig. 8): nos hallamos ante las huellas de un episodio de crioclastia bastante virulento, que alcanzó proporciones suficientes para originar un notable colapso gravitacional de la antigua visera y para provocar con ello un desplome masivo que impactó sobre la totalidad de la planta de excavación de la zona $\mathrm{D}$ exterior ${ }^{9}$. En realidad la precipitada caída de los bloques registrada en la planta de excavación no es más que una muestra de lo que sucedió en buena parte de la terraza $+9 / 11 \mathrm{~m}$. Así se apreció en la primavera del año 2002, cuando al abrir un sondeo de $1 \mathrm{~m}^{2}$ en el cuadro C2, apareció una secuencia casi idéntica a la anotada en la planta general: medio metro de relleno arcilloso rojizo, con una capa compacta, potente, masiva y caótica de clastos que no es más que la prolongación del nivel $4 b$ hacia el sur. Resulta por tanto necesario abordar una descripción minuciosa de este nivel, relevante no solo para comprender la geodinámica del yacimiento, sino para interpretar de manera oportuna el importante nivel cultural musteriense subyacente.

El nivel 4a constituye un depósito heterométrico variable porque reúne gelifractos de distintas formas y tamaños. En la planta abundan los bloques de medianas $(20-30 \mathrm{~cm})$ y de grandes calibres $(>40 \mathrm{~cm}$ ), entre un amasijo de clastos de dimensiones reducidas. Pero en realidad la característica más llamativa es la abundancia de bloques calizos que de largo superan el medio metro de longitud. La mayoría de ellos presentan volúmenes angulosos aunque exhiben en ocasiones unas aristas redondeadas. Entre ellos Ilaman la atención varios bloques masivos, contundentes, colocados con una tendencia subhorizontal, de volúmenes más o menos rectangulares y facetas poliédricas. Bastantes de los grandes clastos adyacentes remontan nítidamente: no son más que los bloques fracturados de unas imponentes masas calizas que se desprendieron de la antigua visera de la cueva, se pre-

(9) El proceso representado por el nivel 4a responde, sin duda, a la dinámica habitual de desmantelamiento de los abrigos rocosos por procesos erosivos de crioclastia, pero a modo de hipótesis no descartamos que pudiera culminar con un efecto de sismicidad, apreciable en numerosos espeleotemas de la sala interior. Esta hipótesis está todavía en discusión pero en todo caso no resulta incompatible con la intervención de procesos de crioclastia. 
Planta de dispersión del derrumbe:

La concordancia entre el nivel $4 \mathrm{~b}$ exterior y 7 interior

El horizonte de derrumbe detectado en la zona D exterior (nivel 4a) impactó por la totalidad de la planta de ocupación musteriense (nivel $4 b$ ) y ocupó por tanto todos los cuadros que hemos excavado. La caída de los clastos ocasióno un flujo turbulento de materiales y la inyección tanto de matriz como de elementos culturales del nivel $4 b$ sobre el nivel $4 a$. Algunos de los clastos más próximos a la pared caliza de la cueva, rodaron en pendiente de manera suave por solifluxión y ocuparon parte de la zona $D$ interior, tal como se puede apreciar en la imagen derecha. En esta zona interior el derrumbe se ha identificado como nivel 7.

En la imagen inferior podemos observar la pauta de distribución de los clastos que componen este horizonte de derrumbe. El ápice del mismo se sitúa en el cuadro E2, que constituye a la sazón la cota más alta del nivel $4 a$ en toda la planta. Desde ese punto los clastos se distribuyen en forma de abanico con una trayectoria general SO-NE. El final de este abanico ocupa los cuadros $\mathrm{H} 4,13$ y $\mathrm{J} 2$.
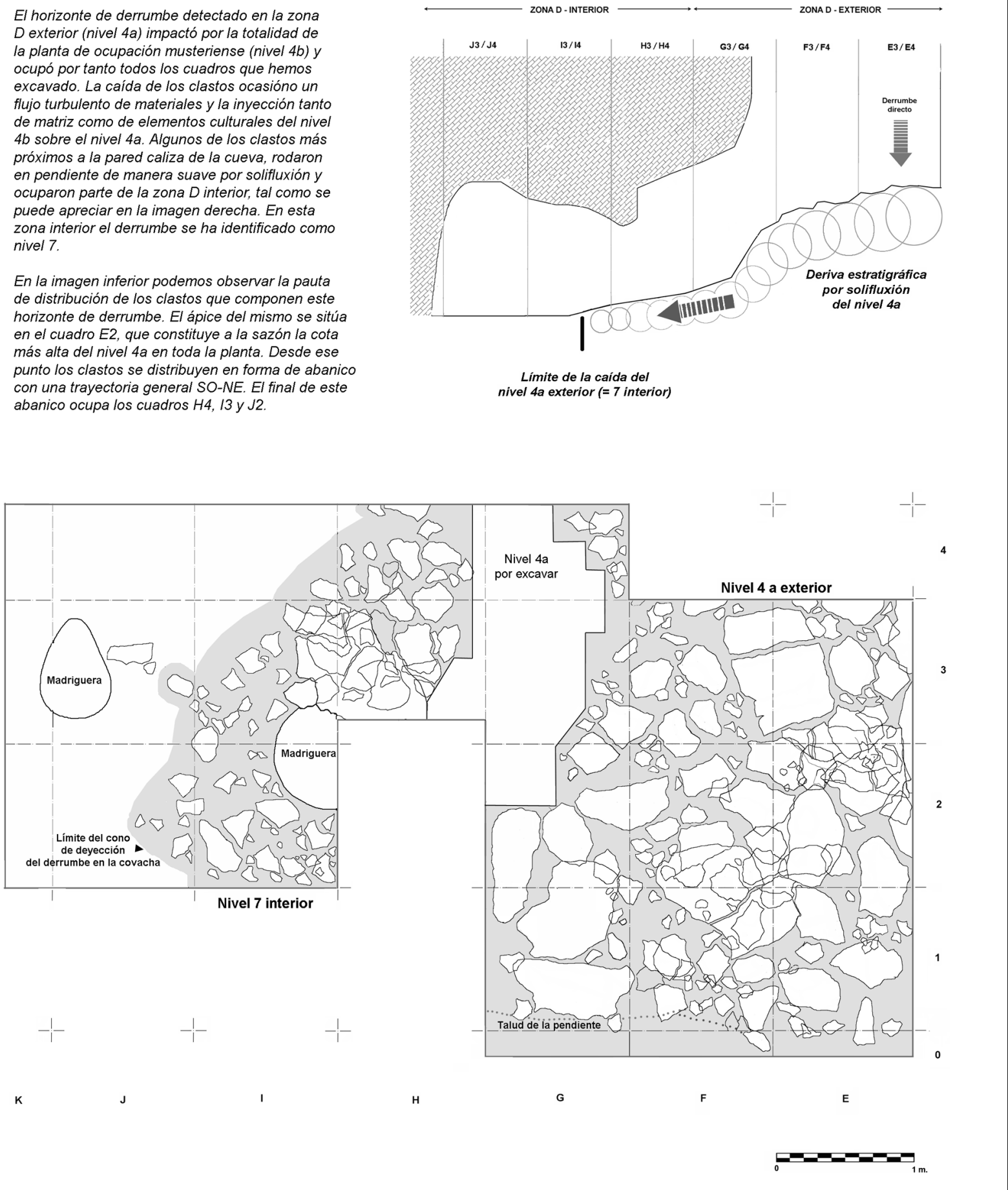

A Figura 8. Planimetría del tramo superior del derrumbe del nivel 4a.

cipitaron al vacío a varios metros de altura, impactaron con extrema violencia sobre el suelo de la terraza y acabaron fragmentados en varios pedazos. La restitución topográfica de estos remontajes permite reconocer muchas de las características del importante colapso gravitacional.
La potencia del nivel oscila de una manera sustancial en función de factores muy diversos, por ejemplo la tasa de acumulación de gelifractos, el volumen de los mismos, la adaptación a los buzamientos del nivel inferior y el ajuste a la pendiente del talud que se interna en la zona D interior. La 
concentración más contundente e intensa de gelifractos se registra en el cuadro E3: los bloques medianos y grandes se amontonan de manera caótica a lo largo de $70 \mathrm{~cm}$ al menos (todavía no hemos alcanzado la base del nivel en tal cuadro), a raíz de una congestión tan violenta y acelerada que no hubo acumulación de matriz a manera de relleno. En contrapartida, la acumulación más ligera se registra en el cuadro E1: aqui se ha reconocido la menor cantidad de bloques, la mayoria de mediano calibre $(>20 \mathrm{~cm}$ ) y cubiertos por una matriz más nutrida. En un estadio intermedio se hallan los cuadros restantes de la banda 1: exhiben una notable carga de bloques pero no muestran la apariencia de congestión caótica de la banda 3 .

Estas disparidades resultan muy importantes a la hora de interpretar de manera correcta los restos culturales. Los cuadros que presentan una mayor carga de clastos están lamentablemente afectados por un marco de preservación muy deficiente. Mientras que en contrapartida, los cuadros menos damnificados por la caída de bloques proporcionan mayores posibilidades para la preservación y suministran mejores resultados de cara a la interpretación del depósito de ocupación. Para apreciar con claridad la carga de los gelifractos y de la evolución de la potencia del nivel $4 a$, podemos acudir al corte de las bandas $D / E$, que muestra en definitiva el perfil transversal de la ladera (fig. 7): la imagen permite comprobar la relativa debilidad del nivel en la banda de cuadros 1, su incremento discreto hacia la mitad de la banda 2, y su engrosamiento notable en la banda 3 .

La potencia variable del nivel depende en gran medida de la escala y dirección de los buzamientos, que representan dos tendencias distintas. La primera es el desplazamiento E0 que perfila la pendiente de la ladera de la terraza. La segunda es el deslizamiento en sentido N-S que conforma el cono de deyección que cae hacia la covacha. Respecto a este buzamiento N-S, la lámina que representa el corte no deja lugar a dudas de una ruptura de pendiente que se produce en la transición entre los cuadros E2/E3 y que, a la sazón, representa la cota superior del nivel $4 \mathrm{~b}$ en la planta. Desde esa cota se registra una dispersión de los gelifractos hacia todas las direcciones a partir de un modelo convencional en abanico.

La sucesión planimétrica de los clastos permite detectar una interesante progresión altimétrica, que se refleja en la densidad, tamaño y morfología. En la base se acumulan los bloques de tamaño grande, próximos a los $40 \mathrm{~cm}$ y de morfologías más redondeadas. En el tramo medio se suceden los bloques de mayor tamaño, de unas dimensiones superiores a los $50 \mathrm{~cm}$, que remontan entre sí (no son más que masas calizas fracturadas al impactar sobre el suelo de la terraza) y ofrecen facetas poliédricas más claras. Esta progresión en el tamaño y morfología de los clastos de base a techo se puede interpretar desde un plano paleoclimático como un incremento progresivo de las condiciones crioclásticas resultado de la intensificación paulatina de unas condiciones ambientales frias/secas.

El desprendimiento crioclástico no incorporó fracción fina, por lo que el nivel 4a no contiene una matriz sedimentaria propia. La prueba de la ausencia de matriz se aprecia en la congestión intensa de bloques que cubrió el cuadro E3: los gelifractos se amontonan de manera anárquica sin arcillas de por medio, dejando intersticios huecos. Pero entonces ¿de dónde procede la matriz arcillosa de relleno entre los derrubios calizos que registramos en otros puntos? Existe una procedencia doble. En las cotas más altas del nivel la matriz no es más que parte del paquete arcilloso rojizo del nivel 3. En las cotas inferiores, la matriz de relleno viene a ser parte de las arcillas marrones que caracterizan el nivel $4 b$, que salieron proyectadas hacia arriba tras el impacto turbulento que generó el hundimiento del derrumbe.

La inyección de la matriz arcillosa del $4 b$ provocó además la incorporación de materiales arqueológicos en la cota del nivel 4a. De esta manera hallamos numerosos huesos y restos industriales, atrapados entre el sedimento de una manera caótica, roturados, quebrados, los unos sobre los otros en enorme desorden, compactados entre los gelifractos y en una disposición habitualmente vertical (fig. 9). El implacable impacto y la posterior presión que sufrieron muchos de los materiales engendraron condiciones muy perniciosas para la preservación del registro cultural, en particular para los sensibles restos óseos. La mayoría de los huesos que se acumulan en el nivel 4a no son más pequeños fragmentos triturados y fracturados, simples esquirlas amontonadas en desorden entre el amasijo de bloques, con numerosas alteraciones postdeposicionales.

En los restos óseos del nivel menudean los rastros de alteraciones corticales relacionadas con procesos de exposición al aire libre. Dentro de esta categoría son numerosas las huellas de exfoliaciones, muestra muy evidente de que el amasijo (compuesto por las calizas desprendidas, por los numerosos huesos y por restos industriales) permaneció expuesto al aire libre durante cierto tiempo. Las trazas de exposición aérea abundan también entre los clastos, particularmente en aquellos depositados entre los tramos superiores del nivel. $Y$ en esta misma línea apunta también la presencia nutrida de restos de micromamíferos y de gasterópodos, que se aprecian en cotas superiores del nivel 4a. En suma todos estos indicios permiten entrever que la planta de derrumbe caótica permaneció al aire libre y ofreció un refugio perentorio para pequeños animales, sobre todo carnivoros, que aprovecharon los huecos entre las piedras y bajo la visera para acomodar madrigueras. Por entonces aún quedaba un pequeño agujero para acceder hacia el interior de la covacha: este orificio fue el que permitió el acceso de pequeños animales hasta la superficie del nivel 8 (zona D interior) que horadaron en algunos puntos, alli donde no se depositaron los bloques calizos del final del cono. 


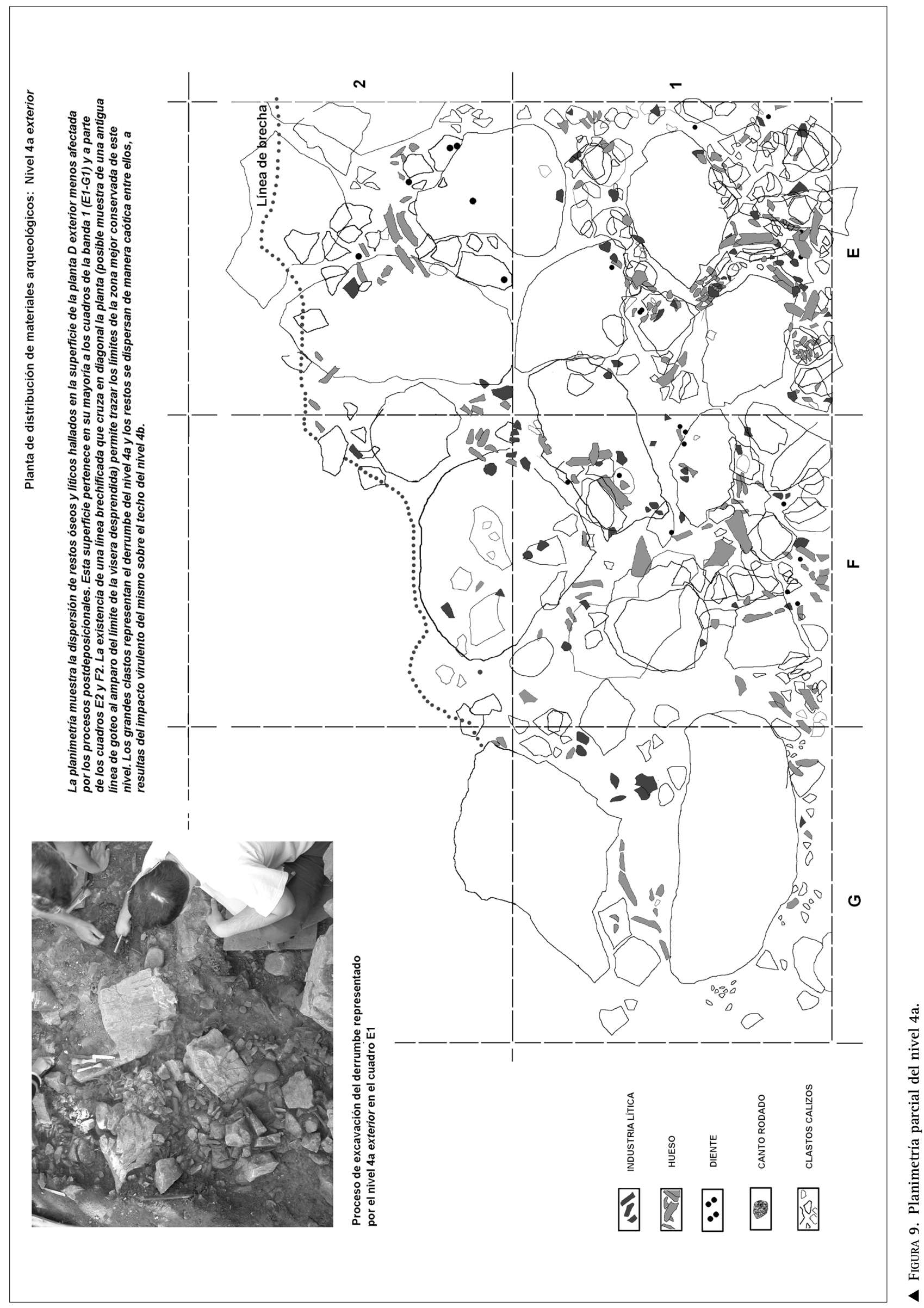




\subsection{La ocupación musteriense: Nivel $4 \mathrm{~b}$}

Bajo la contundente capa de derrubios aparece el llamado nivel $4 b$, que no en vano representa el depósito cultural más relevante exhumado hasta ahora en la terraza o zona $\mathrm{D}$ exterior. Este nivel responde a una ocupación humana muy intensa que se desplegó por toda la plataforma de la terraza, bajo la protección de una antigua y extensa visera que con toda probabilidad se extendía ampliamente sobre el terreno. El nivel $4 \mathrm{~b}$ ocupaba originariamente los $10 \mathrm{~m}^{2}$ de la planta de excavación pero la impactante devastación originada por el derrumbe 4 a desmanteló hasta tal punto la disposición original que desde un punto de vista técnico solo podemos reconocer retazos más o menos explícitos del mismo en unos 6-7 $\mathrm{m}^{2}$. La mejor imagen de este nivel se halla en los cuadros E3 y F2, y parcialmente en $\mathrm{G} 1$ y $\mathrm{G} 2$, lo que representa unos $4.5 \mathrm{~m}^{2}$.

\section{Estratigrafía y sedimentología:}

En términos generales, el nivel posee una matriz arciIlosa marrón relativamente plástica y un buzamiento SO-NE un tanto discreto, pero que se acrecienta paulatinamente en la medida que nos acercamos a la pared caliza norte. En los cuadros con una mejor preservación la potencia media se mantiene en $30 \mathrm{~cm}$, una medida basada en la densidad de materiales arqueológicos pues en realidad no hay una discontinuidad estratigráfica respecto del nivel 4c. En este sentido tenemos que reconocer que la caracterización del nivel reposa en la producción arqueológica: se trata de un nivel de naturaleza eminentemente cultural, hasta el punto de que la base del nivel reposaen unas arcillas similares pero ya estériles.

Pero tras estas caracteristicas generales se pueden hallar matices importantes en el plano sedimentario, que avalan la complejidad taxonómica del depósito y que, a la postre, resultan imprescindibles para una comprensión verosímil del registro arqueológico. Las principales variaciones que se pueden contemplar afectan a tres parámetros: textura y tonalidad de la matriz; composición de la fracción gruesa; y finalmente procesos locales de precipitación de carbonatos.

a) La textura y la tonalidad de la matriz. Buena parte de los cuadros que componen la banda 1 poseen una matriz bastante plástica y una tonalidad marrón levemente oscura, que revelan una relativa acumulación de materia orgánica. Por el contrario, buena parte de los cuadros que integran la banda 2 se caracterizan por una matriz poco plástica, arenosa y amarillenta. Estas discrepancias se aprecian incluso en la distribución vertical, tal como reflejan perfectamente los cuadros $\mathrm{G} 1$ y $\mathrm{G} 2$. En ambos casos la matriz que rellena las cotas superiores presenta una textura arenosa y una tonalidad clara, probablemente por la intervención localizada de procesos de lavado y precipitación carbonatada. A medida que progresamos en profundidad la matriz experimenta un aumento de la plasticidad y un oscurecimiento, que coinciden con la mejoría en la preservación del registro y la reducción drástica de los procesos de lavado.

b) La constitución de la fracción gruesa. En líneas generales entre la matriz aparecen numerosos clastos repartidos de manera generalizada por la totalidad de la planta. La mayoría de los bloques registrados son de dimensiones medianas pues presentan un promedio de $30-10 \mathrm{~cm}$. No faltan algunos ejemplares de mayores dimensiones, próximos a los $40 \mathrm{~cm}$. En cualquier caso han desaparecido los grandes bloques que representaban el compacto horizonte de derrumbe crioclástico del nivel 4a. Pero tras esta descripción breve podemos detectar una gradación altimétrica muy clara en la dispersión del componente grueso. En la base del nivel $4 b$ hay una cantidad reducida de clastos, la mayoría de pequeñas-medianas dimensiones $(20-10 \mathrm{~cm})$. Hacia el tramo medio se aprecia un incremento del número de clastos y un aumento notorio de las dimensiones medias $(30-20 \mathrm{~cm})$. Esta gradación altimétrica culmina con un tercer estadio, con los bloques compactos de grandes dimensiones que representa el horizonte de colapso gravitacional del nivel 4a. Esta gradación altimétrica de los clastos que se registra desde la base del nivel $4 b$ hasta el $4 a$ puede interpretarse en clave paleoclimática: un proceso de crioclastia de gran alcance, particularmente revelante para ahorquillar con bastante precisión la cronología del nivel de ocupación.

c) Los procesos de carbonatación. Hay otro elemento muy importante a la hora de valorar de manera correcta el nivel: la proliferación en planta de numerosas huellas de precipitación de carbonatos, la mayor parte relacionados con los procesos de goteo que concurren entre las viseras calizas. Los retazos de capas brechificadas recubren toda la planta y aparecen por doquier: entre su matriz arcillosa, sobre clastos calizos, cubriendo fragmentos de huesos y restos de industria. Las huellas de carbonatos presentan múltiples apariencias. Hay pequeñas capas de carbonatos cubriendo levemente muchos clastos, sobre todo aquellos ubicados en el tramo más alto del nivel. Hay otras capas carbonatadas adheridas en superficies de huesos y restos industriales, lo que suele acontecer por la totalidad de la planta. Hay masas compactas brechificadas integras entre los sedimentos, sobre todo en los cuadros centrales. Pero también hay fragmentos de brechas compactas rotas, que aparecen básicamente en los cuadros próximos al 
talud de la ladera. Finalmente, hay retazos parciales de las distintas líneas de goteos que se sucedieron con el retroceso paulatino de la visera. El carácter fragmentario de muchas de las huellas (líneas de goteo parciales, brechas compactas fracturadas, etc.) no es más que un resultado más del profundo destrozo que provocó la caída de los bloques del nivel 4 a. Por tales razones, el conocimiento de la variedad de trazas relacionadas con la precipitación de carbonatos, resulta fundamental no solo para la pertinente interpretación cronoestratigráfica y paleoambiental del depósito, sino para la reconstrucción tafonómica del registro cultural.

La precipitación de carbonatos y el colapso gravitacional han convertido los tramos superiores del nivel $4 \mathrm{~b}$ en un palimpsesto de complicada interpretación, en un registro profundamente supeditado a factores postdeposicionales. En realidad nos hallamos ante un nivel desmantelado en buena medida por la geodinámica sedimentaria, hasta tal punto que buena parte del mismo proporciona una «baja resolución arqueológica». Pero no todos los cuadros han padecido con el mismo rigor este cúmulo de alteraciones postdeposicionales. Hay cuadros que han experimentado una profunda transformación de la ocupación originaria; y los hay que han conservado retazos de aquella imagen originaria. En consecuencia, no todos los cuadros de la planta ofrecen las mismas condiciones para reconstruir de manera verosímil la habitación original del nivel $4 \mathrm{~b}$. Los cuadros que forman la banda 1 (E1-G1) proporcionan unas mejores expectativas pues han padecido con menor inclemencia los rigores de tanto proceso postdeposicional. Los cuadros de la banda 2 (E2-G2) ofrecen una imagen más compleja, más borrosa, porque experimentaron con mayor severidad los crudos efectos de la carbonatación y del colapso gravitacional. Pensemos que esta última banda recibió el impacto de gran cantidad de bloques y posteriormente soportó su enorme carga, hasta tal punto que el imponente peso de algunos gelifractos originó el hundimiento de parte del depósito y ejerció una intensa presión en los restos arqueológicos. Estas condiciones resultaron perniciosas para los materiales arqueológicos más sensibles, particularmente para los huesos, que aparecen en un lamentable estado de preservación.

La matriz arcillosa con presencia moderada de clastos del nivel $4 b$ progresa en profundidad de una manera paulatina y sin solución de continuidad. Las arcillas van ganando en plasticidad y perdiendo clastos, en paralelo a la reducción del material arqueológico. Esta progresión se desarrolla a lo largo de unos $10 \mathrm{~cm}$ de espesor medio y comprende un buzamiento SE-NO similar al reconocido en 4 b. Debido a las particularidades de tan pequeño tramo convenimos en denominarlo nivel 4c. Desde el punto de vista cultural, hay una reducción progresiva del material arqueológico, tanto de huesos como de industria. Nos hallaríamos por tanto ante las primeras etapas de la ocupación musteriense del nivel, todavía con cierto carácter de tanteo. Pero para el tramo inferior del nivel $4 c$ también podríamos pensar en la posibilidad de una percolación de materiales. Estas ideas no pasan por ahora de hipótesis.

La evolución representada por el nivel anterior finaliza en el nivel 5 . Se trata de un depósito potente de arcillas más o menos plásticas y color marrón generalizado. La proporción de la fracción gruesa es relativamente reducida, aunque en ocasiones presenta clastos de mediano tamaño. Todavía no conocemos su potencia completa pero un sondeo que realizamos en el cuadro G1 permite evaluar por ahora su espesor en torno al medio metro como mínimo. Desde el punto de vista cultural es completamente estéril.

\section{Registro óseo e Industria:}

La banda de cuadros 1 suministra una muestra muy representativa del contenido arqueológico del nivel. En su planta se amontona un conglomerado compacto formado por pequeños restos óseos fracturados, productos de talla dispares y útiles tallados sobre todo en cuarcitas (fig. 10). El material cubre la planta de manera muy generalizada y no presenta aparentemente patrones de dispersión, si bien en esta circunstancia está mediatizada por los procesos postdeposicionales por lo que tenemos que esperar los resultados analíticos de las planimetrías. Lo que por ahora parece claro es que en aquellos puntos con una mejor preservación postdeposicional hay ciertos indicios posiblemente reveladores de patrones de organización espacial. Así sucede por ejemplo en un tramo relativamente profundo del cuadro $\mathrm{G} 1$, donde una matriz arcillosa plástica recubre las huellas de una concentración de minúsculos puntos de carbón, con restos de talla de diversos tamaños (incluyendo microdesechos líticos inferiores a $5 \mathrm{~mm}$ ), varios útiles, y una pieza dental humana de probable filiación neandertal ${ }^{10}$.

Pero la peculiaridad más llamativa de los primeros tramos del nivel $4 b$ reside en la ausencia de unas pautas nitidas de distribución espacial, por el vasto desmantelamiento

$\left.{ }^{10}\right)$ La pieza dental se halla actualmente en proceso de estudio (Trancho, G.J., Dpto. Zoología y Antropología Física, Facultad de Biología, UCM). Pero podemos avanzar de manera preliminar que se trata del segundo premolar de un individuo que superó los 15 años -a juzgar por nuestro patrón de desarrollo- y que presenta un estado de desgaste 3. La antigüedad de las dataciones ${ }^{14} \mathrm{C}$ que hemos obtenido de una muestra de hueso recogida en ese cuadro y a una cota pareja, junto a las dimensiones y caracteristicas de la pieza, podemos apuntar por su pertenencia neandertal (más datos al respecto en Menéndez et alii, 2009: 216-217). 

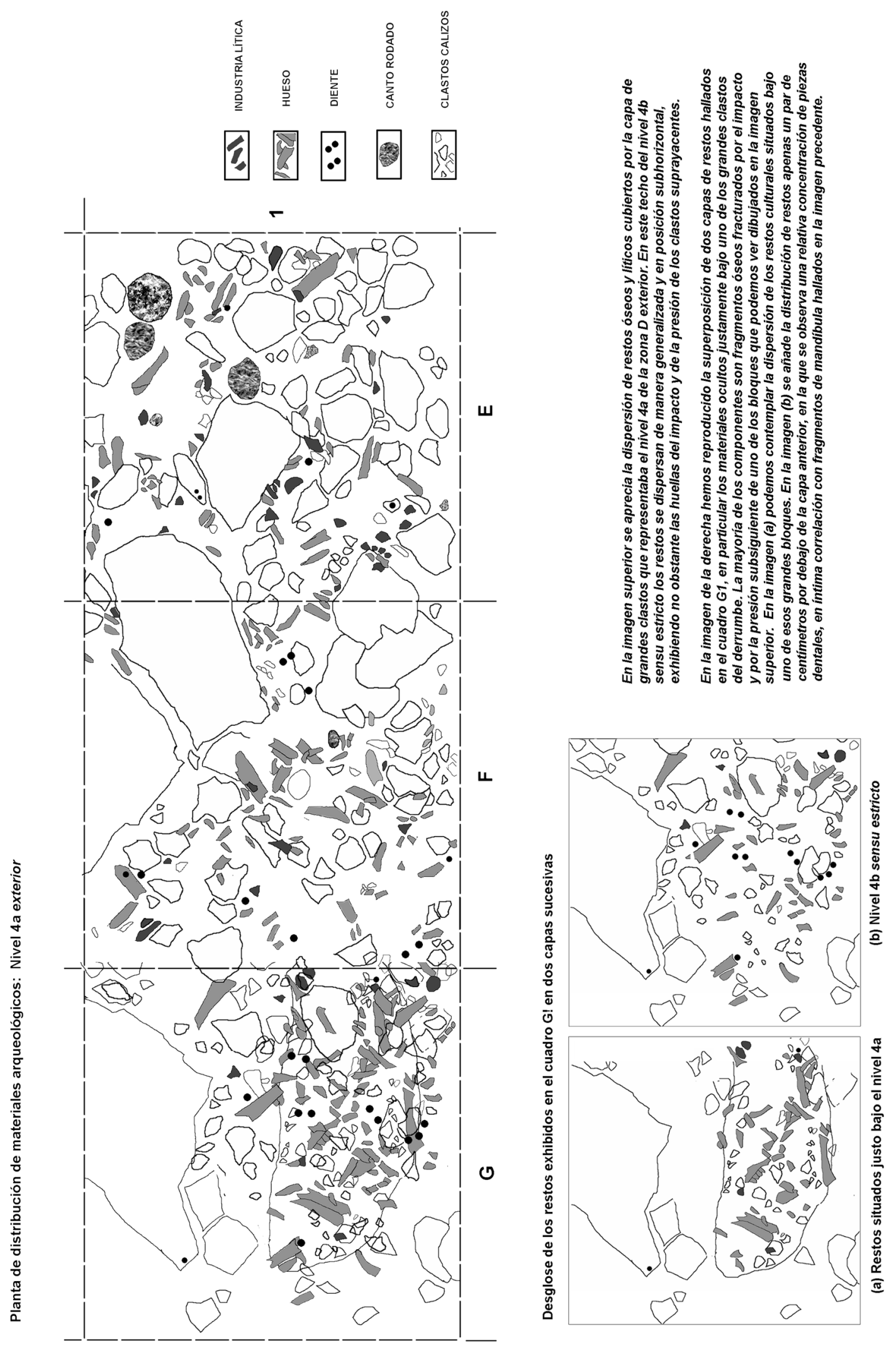
de los múltiples procesos postdeposicionales. Basta analizar los numerosos restos óseos recuperados en los cuadros E1 y F1 para comprobar en qué medida han sido nocivos los procesos originados por el derrumbe 4a. La mayoría de los fragmentos óseos no presentan más de $5 \mathrm{~cm}$ de longitud, resultando numerosas las esquirlas de menor tamaño y por lo común inidentificables. Entre los restos abundan las partes del esqueleto que tienen mejor potencial de conservación, como los dientes y metápodos; así como los que cuentan con unas mejores posibilidades de identificabilidad, como las falanges. Estos dos rasgos son los típicos de aquellos registros intensamente sometidos a la destrucción postdeposicional. En cuanto a los procesos de brechificación, han dejado otras huellas en la superficie de los huesos como capas carbonatadas, concreciones calcáreas corticales, abrasiones y efectos de redondeamiento en los bordes fracturados. En suma una historia tafonómica ósea larga y compleja, cuya interpretación es a todas luces imprescindible para conocer la génesis del nivel.

El conjunto industrial recuperado en los niveles $4 a-4 b$ presenta las atribuciones de un marco musteriense clásico. Nos hallamos en un momento preliminar de los estudios líticos, pero las primeras valoraciones en la materia permiten presentar unas líneas industriales básicas. Desde el punto de vista tipológico destaca la relativa diversidad del repertorio instrumental, que apunta a priori hacia un amplio rango de actividades. Desde una perspectiva tecnomorfológica, la mayoría de las piezas reproducen patrones relacionados con una limitada inversión de trabajo, muy posiblemente con un marco oportunista de talla. La partida de útiles más numerosa la componen lascas retocadas de muy pequeñas dimensiones, con siluetas heterogéneas y retoques simples bastante nítidos pero de recorrido muy limitado, que en numerosos casos presentan escotaduras. Desde el punto de vista tipológico, este tipo de piezas podrían interpretarse como raederas someras pero podrían pasar también por meras escotaduras. En realidad las raederas convencionales no resultan numerosas. Entre ellas hallamos un amplio repertorio (dobles, desviadas, transversales, de dorso natural, de dorso adelgazado) pero también una relativa uniformidad tecnomorfológica, bajo una serie de patrones similares: la mayor parte aparecen talladas sobre soportes consistentes (lascas medio/grandes), presentan retoques profundos (aunque no hay ejemplares quina), y en ocasiones pequeñas muescas bien talladas o filos denticulados. No podemos terminar este breve repaso a la industria lítica sin hacer una referencia al componente levallois, que tiene su mejor representación en varios ejemplares de puntas de tamaño mediano y factura muy cuidada.

\section{Radiocronología:}

Hasta no hace mucho la cronología del nivel $4 b$ resultaba incierta pero las dataciones radiocarbónicas que hemos obtenido recientemente han permitido ahorquillar con bastante rigor su posición en un contexto de indiscutible asignación musteriense. En nuestras primeras publicaciones la impronta musteriense que se apreciaba en la industria no encajaba muy bien con las dos dataciones ${ }^{14} \mathrm{C}$ obtenidas inicialmente para el nivel. Dos dataciones que coincidian en emplazar el nivel 4 en un momento bastante tardío, grosso modo en torno al 30.000 B.P. (Menéndez, García y Quesada, 2005: 610). En concreto, la primera datación ${ }^{14} \mathrm{C}$ AMS/hueso proporcionó una fecha $29.550 \pm 310$ B.P. (Beta-172345) para el nivel 4a (Menéndez, García y Quesada, 2005: 600). La segunda datación, también ${ }^{14} \mathrm{C}$ AMS /hueso, revalidó la baja cronología al proporcionar la fecha del $29.020 \pm 260$ B.P. (Beta-186766) para el nivel 4b (Menéndez, Garcia y Quesada, 2005: 600). La paradoja entre una industria de rasgos musterienses y una fecha reciente impuso una relativa prudencia en las primeras valoraciones, por lo que optamos por mantener en cuarentena tanto la filiación Chatelperronense como la de Musteriense final (Menéndez, García y Quesada, 2005: 603).

Para resolver este dilema procedimos a recoger una nueva batería de muestras en la campaña del 2007. Las diez muestras de hueso escogidas procedian de los sectores mejor preservados del nivel $4 \mathrm{~b}$ y todas ellas presentaban marcas de actividad antrópica que certificaban una génesis cultural. En el laboratorio 0xford Radiocarbon Accelerator Unit (ORAU) aplicaron los oportunos protocolos de calidad y los métodos de limpieza química para asegurar las mejores garantías analíticas ${ }^{11}$. De las diez muestras seleccionadas el laboratorio descontó seis porque carecian de colágeno suficiente pero reconoció en las cuatro restantes los requisitos oportunos para una analítica solvente. Los resultados que hemos obtenido de las muestras no dejan lugar a dudas y resuelven la incertidumbre inicial. Dos presentan las fechas $>43.200$ B.P. (0xA-20123) y >43.600 B.P. (0xA-20125). Las dos restantes permiten ahorquillar mejor el nivel al proporcionar las fechas siguientes: $47.400 \pm 2.700$ B.P. (OxA-20122) y $48.500 \pm$ 3.500 B.P. (0xA- 20124). En suma, la combinación de las cuatro nuevas dataciones sitúa el nivel $4 b$ grosso modo en la horquilla 43.000-53.000 B.P. sin calibrar, y avala la atribución a un «Musteriense pleno tardío».

(11) El protocolo de pretratamiento de muestras que se aplica en el Laboratorio "Oxford Radiocarbon Accelerator Group" (ORAU) recurre al procedimiento de la infiltración para la purificación del colágeno (véase por ejemplo Higham et alii, 2006). Este método ha permitido eliminar los residuos de carbonatación de los huesos, un aspecto fundamental en el caso de La Güelga por la abundancia de procesos de brechificación. 


\section{LA GÉNESIS ESTRATIGRÁFICA DEL YACIMIENTO}

En el momento actual de la investigación en La Güelga podemos plantear un ensayo bastante solvente acerca de la secuencia estratigráfica general de la zona $D$, en el que concurre una complicado proceso geomorfológico con sucesos de erosión y sedimentación por otra parte habituales en este tipo de medios kársticos. El yacimiento que nos ocupa posee una historia geodinámica complicada, en la que concurren tres procesos: un proceso de sedimentación intenso, que a la postre originó una colmatación completa de la cueva; una actividad de erosión fluviocárstica que provocó un notable encajamiento del valle y puede que la pérdida de parte de la secuencia arqueológica; y un proceso bastante violento de crioclastia que generó la pérdida de la visera antigua y que muy probablemente arrastró parte de los niveles del Paleolítico superior inicial. En este sentido nuestro trabajo parte de un presupuesto inevitable a la hora de interpretar un registro arqueológico: cualquier interpretación integral y coherente requiere la simbiosis coherente de resultados estratigráficos, valoraciones radiocronológicas, procesos geodinámicos generales y vicisitudes geoarqueológicas puntuales de índole geológica y biológica (Zilhão, 2006: 68).

En el caso que nos ocupa la reconstrucción ha resultado más compleja si cabe por la intervención de fenómenos erosivos puntuales pero localizados en puntos bastante estratégicos para comprender el yacimiento. Nos estamos refiriendo en concreto a las removilizaciones relacionadas con los procesos de bioturbación que han desmantelado un punto tan sensible de la estratigrafía como la conexión entre las zonas D exterior e interior. Las madrigueras y las raices destrozaron la concordancia estratigráfica entre los niveles 1-6 de la covacha y los niveles 1-3 de la terraza, complicando sobremanera la comprensión del yacimiento. En la actualidad disponemos de un modelo interpretativo convincente de lo que pudo suceder en la complicada historia sedimentaria.

\section{Fase I}

Primeras ocupaciones musterienses (Nivel 4c):

Los primeros rastros de una actividad humana aparecen en el nivel 4c. Este es el punto de partida de un episodio de habitación humana que constituyó el último ciclo de la ocupación musteriense del yacimiento. En aquel momento las condiciones de colmatación de la caverna se hallaban probablemente muy evolucionadas y habrian restringido el acceso al vestíbulo interior de la cueva. La pobreza de los restos del nivel 4c apunta hacia una limitada presencia humana, que podria interpretarse a partir de un régimen de ocupación esporádico, quizás ocasional (una hipótesis a contrastar con el estudio de los materiales.

\section{Fase II}

La ocupación musteriense principal (Nivel 4b):

En la transición hacia el tramo inferior del nivel $4 b$ pueden percibirse las primeras pruebas de una intensificación del régimen de ocupación de la cueva. El aumento sustancial de los restos culturales y su distribución generalizada por la totalidad de la planta de la zona D exterior revela hasta qué punto la cueva se convirtió en punto de referencia en la ocupación del territorio. Nuestros primeros datos avalan que la intensificación prosiguió en el tramo medio del nivel $4 \mathrm{~b}$. La riqueza arqueológica de este tramo revela con toda probabilidad un régimen de ocupación intenso, que por la batería de dataciones radiocronológicas podemos situar grosso modo en la horquilla 45.000-50.000 B.P. (sin calibrar). La imagen sedimentológica que nos proporciona este nivel apunta una hipótesis interesante: el incremento de la ocupación operó bajo un período de empeoramiento climático paulatino, a juzgar por el aumento de las condiciones crioclásticas que exhibe de base a techo el nivel.

La riqueza arqueológica permanece latente hacia el tramo superior del nivel $4 b$. Pero lamentablemente las huellas de lo que pudieron ser las ocupaciones terminales aparecen transfiguradas por el impacto postdeposicional que originó el derrumbe por colapso gravitacional de la visera. De esa manera, la imagen de la habitación originaria desapareció para dar paso al palimpsesto caótico del nivel 4a, que nos proporciona la cantidad de restos materiales conveniente para su precisa caracterización industrial pero no posee la resolución suficiente para reconocer la disposición original de los restos. En tal punto podemos recurrir a la analítica radiocronológica, a una comparativa de las dataciones ${ }^{14} \mathrm{C}$ entre los niveles $4 \mathrm{~b}$ exterior y 8 interior, de consecuencias trascendentales para una interpretación integra oportuna de la secuencia del yacimiento (Menéndez et alii, 2009: 207). El estudio riguroso de las dataciones radiocronológicas permite mantener por ahora dos hipótesis de contemporaneidad:

A. La primera hipótesis parte por concebir mayor antigüedad al nivel 4 exterior (tramo medio). Las dataciones obtenidas del nivel 8 interior son levemente más recientes, por tanto podrian ser coetáneas del tramo superior del nivel $4 \mathrm{~b}$ o ya del nivel 4a. Es decir nos hallariamos en la covacha con la imagen preservada de lo que fue la habitación original de la terraza.

B. La segunda hipótesis apuesta por un solapamiento parcial a dos sigmas de las dataciones. Esta perspectiva rebaja la cronología de los niveles 8-9 interior y permite respaldar la estricta contemporaneidad con el tramo medio del nivel $4 b$ exterior.

En cualquiera de los dos casos persevera la concordancia estratigráfica $4 \mathrm{~b}$ exterior \# 9 interior. Esta correspondencia permite reconocer bajo una misma unidad de ocupación el palimpsesto anárquico que cubre la terraza y las múltiples estructuras de combustión in situ preservadas 
Tabla 1. Batería de dataciones ${ }^{14} \mathrm{C}$ de la Cueva de La Güelga

\begin{tabular}{|c|c|c|c|c|c|c|c|}
\hline Zona & Niveles & Material & Método & $\begin{array}{c}\text { Referencia } \\
\text { laboratorio }\end{array}$ & $\begin{array}{c}\text { Fechas B.P. sin } \\
\text { calibración }\end{array}$ & 1 sigma (B.P.) & 2 sigmas (B.P.) \\
\hline D interior & 9 & Hueso & AMS & OxA-19244 & $43.700 \pm 800$ & $42.900-44.500$ & $42.100-45.300$ \\
\hline D interior & 9 & Hueso & AMS & OxA-19245 & $44.300 \pm 1.200$ & $43.100-45.500$ & $41.900-46.700$ \\
\hline D exterior & $4 b$ & Hueso & AMS & OxA-20122 & $47.400 \pm 2.700$ & $44.700-50.100$ & $42.000-52.800$ \\
\hline D exterior & $4 b$ & Hueso & AMS & OxA-20123 & $>43.200$ & - & - \\
\hline D exterior & $4 b$ & Hueso & AMS & OxA-20124 & $48.500 \pm 3.500$ & $45.000-52.000$ & $41.500-55.500$ \\
\hline D exterior & $4 b$ & Hueso & AMS & 0xA-20125 & $>43.600$ & - & - \\
\hline & & & & & & & \\
\hline Cono interior & Tramo superior & Hueso & Convencional & GrN-8256 & $32.000 \pm$ & & - \\
\hline D interior & 1 & Hueso & AMS & Beta-172343 & $32.460 \pm 440$ & $32.020-32.900$ & $31.580-33.340$ \\
\hline D interior & 2 & Hueso & AMS & Beta-172344 & $30.210 \pm 340$ & $29.870-30.550$ & $29.530-30.890$ \\
\hline D exterior & $4 a$ & Hueso & AMS & Beta-172345 & $29.550 \pm 310$ & $28.930-29.860$ & $29.240-30.170$ \\
\hline D exterior & $4 b$ & Hueso & AMS & Beta-186766 & $29.020 \pm 260$ & $28.760-29.280$ & $28.500-29.540$ \\
\hline
\end{tabular}

nítidamente en la covacha. De este modo la detallada sucesión de los horizontes de combustión que discurre desde la base del nivel 9 hasta el techo del nivel 8 proporciona una imagen detallada de la evolución del régimen de ocupación en los tramos medio/superior del nivel 4 exterior: considerando la sucesión estratificada de la covacha podriamos pensar en un progresivo declinar en la intensidad de hábitat y en una rarificación de la densidad de ocupación.

Las discrepancias tafonómicas entre los niveles 9 interior y $4 \mathrm{~b}$ exterior no son razones para impedir la concordancia estratigráfica pues obedecen a las historias geodinámicas particulares de cada zona. El tramo superior del nivel 4 b y el nivel 4a ofrecen pocas posibilidades para reconocer la planta originaria, perdida por el violento impacto inmediato del derrumbe [flujo turbulento] que trastornó la ocupación originaria en un amasijo caótico y anárquico. Los niveles 8-9 interior permiten reconocer de inmediato lo que fue su planta de habitación, pues la covacha protegió el suelo del impacto directo del derrumbe y los pocos bloques calizos que se deslizaron por la pendiente no poseian la energía suficiente para crear un grave trastornos, penetrando de manera discreta por la covacha y se depositaron sin más adaptándose suavemente al sustrato del nivel 8.

La concordancia estratigráfica entre estos niveles permite desplegar en el futuro próximo sugestivas expectativas de estudio. Entre ellas resultan particularmente interesantes las hipótesis de investigación implicadas en la variabilidad logística interna, a partir de la lectura etnoarqueológica de la distribución espacial de los restos ${ }^{12}$. En el caso que nos ocupa la planta de excavación resulta bastante pequeña para emprender una interpretación en este sentido, pero nos pro- porciona algunos indicios de un posible reparto de actividades de acuerdo con una variabilidad funcional. Las primeras valoraciones parecen apuntar que la planta de la zona exterior pudo haber representado el área central de habitación, una especia de área doméstica en cierto modo parecida a un área "drop" (Binford, 1978, 1988). Mientras que la pequeña planta de la zona interior pudo ser tan solo un área periférica que albergó actividades marginales de combustión a manera de una zona "toss» (Binford, 1978, 1988).

Fase III

Derrumbe de la visera (Nivel 4a):

El derrumbe representado por los bloques del nivel 4a se precipitó sobre la superficie de ocupación musteriense del nivel $4 b$, y tal vez pudiera haber motivado el abandono de la cueva como lugar de habitación. Lo que sí parece cierto es que este horizonte de derrumbe fue el último capítulo del proceso paulatino de empeoramiento climático que se inició en la base del nivel 4c y ahorquilló toda la ocupación musteriense.

La mayor parte de este colapso gravitacional está representado por el nivel 4a exterior pero una pequeña parte se corresponde con la pequeña acumulación del nivel 7 interior. La concordancia estratigráfica entre los dos niveles se ha preservado en los cuadros $\mathrm{H} 3$ y H4, bajo la débil capa apelmazada que sirvió de base a la madriguera. La reconstrucción integral en planta no deja lugar a dudas: el nivel 7 interior representa simplemente la cuña terminal del amplio abanico de dispersión del nivel 4a exterior, su prolongación hacia el interior del karst merced a la caída de unos pocos gelifractos por el desnivel que separa ambas zonas (fig. 11). La pendiente de caída resultó tan moderada que

${ }^{(12)}$ El ejemplo de este tipo de trabajos se halla en el yacimiento de Abric Romaní, que ha dado lugar a una amplia sucesión de trabajos con el propósito principal de aportar una interpretación paleoetnográfica de las unidades de ocupación, y que podría servir coo referencia para los registros musterienses peninsulares (Chacón y Fernández-Laso, 2007: 56-58). 


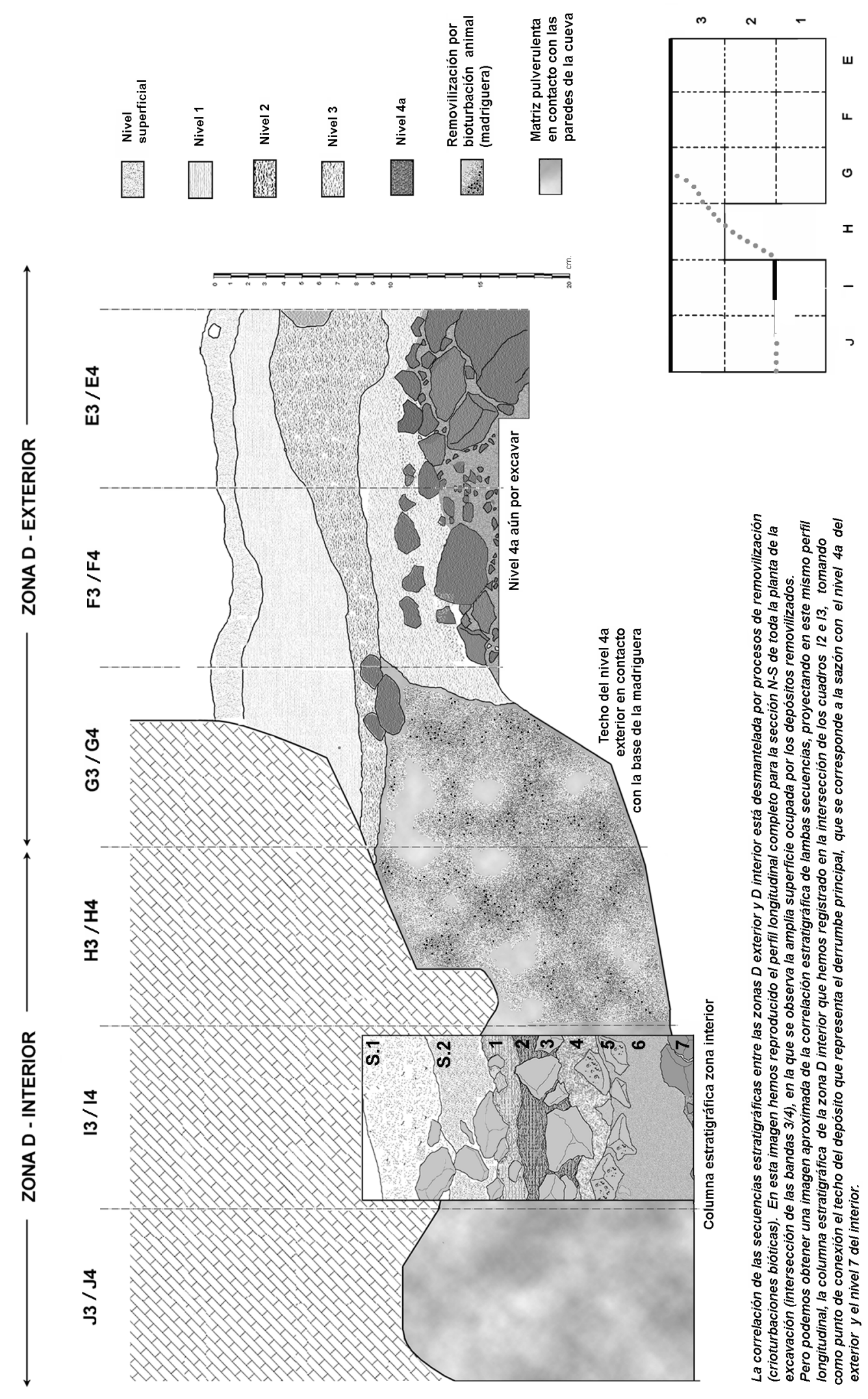


los bloques no penetraron profundamente ni llegaron a cubrir la planta completa de la covacha. Los gelifractos se deslizaron suavemente por la planta de habitación del nivel 8 interior (baja energía) y la imagen de la ocupación se conservó casi intacta. De ahí la excelente preservación del suelo de habitación en la covacha, la disposición horizontal de los materiales, la buena conservación de restos y la sucesión estratificada in situ.

\section{Fase IV}

Los depósitos Paleolítico superior inicial (Niveles 1-6 exterior)

Después de la habitación musteriense la cueva albergó la secuencia de ocupación del Paleolítico superior inicial. En realidad poco queda de esa secuencia de transición en La Güelga: en términos geológicos constituye un pequeño cono de deyección con un componente gravitacional muy relevante, que rellena el angosto hueco de la covacha. La columna estratigráfica preservada en tal lugar no es más que el reducido retazo de una superficie arqueológica más amplia que se pudo extender por parte de la terraza y que pudo ser arrasada por procesos de erosión hasta tal punto que solo se conserva actualmente en la zona que hemos llamado repisa. El buzamiento de la columna que hemos exhumado muestra hasta qué punto es una prolongación de ese retazo arqueológico de la repisa. Desde luego, no conviene perder este contexto al encarar los interrogantes y las sospechas que desprende la interpretación de esta unidad estratigráfica. Destaquemos tres de ellos por ahora como muestra de la problemática especifica que aqueja el muestrario de niveles.

El primero reside en la reducida representación en planta, particularmente para los niveles chatelperronenses. Es tal la limitada planta exhumada que podríamos interpretar la columna como un mero sondeo y la pequeña cantidad de restos recuperados como muestras precarias, dificultando notoriamente su extrapolación y comparación con niveles cantábricos de similar atribución industrial. Para sortear tal inconveniente bastaría con ampliar la zona de excavación hacia la repisa, lo que permitiría encuadrar mejor toda esa secuencia y ahondar en la génesis geosedimentaria que a la postre es la mejor solución para contextualizar de modo oportuno esta columna.

La segunda sospecha reside en la inversión estratigráfica Chatelperronense -Auriñaciense. En esta cuestión resulta imposible eludir las conclusiones propuestas por la actual revisión estratigráfica de El Pendo (Sanguino y Montes, 2001: 277). En el caso de La Güelga hemos de destacar que los dos unidades industriales poseen una indiscutible homogeneidad industrial interna y aparecen separados por una capa intermedia estéril que avala la integridad industrial. No obstante, el marco sedimentario acusa una serie importante de objeciones para asegurar una viabilidad de la secuencia, a saber: la deriva estratigráfica que se aprecia desde el exterior; la probable intervención de procesos erosivos intensos de parte de los niveles; y la limitada resolución en planta.

El tercer interrogante concurre en la ubicación cronológica del tramo chatelperronense. En los trabajos publicados ya hace cinco años se dieron a conocer las dos dataciones radiocarbónicas obtenidas a partir del ${ }^{14} \mathrm{C}$ AMS/hueso de los niveles 1 y 2 (Menéndez, García y Quesada, 2005:595). La muestra tomada junto a la punta de Chatelperron típica del nivel 1 proporcionó la fecha de $32.460 \pm 440$ B.P. (Beta172343). La muestra alternativa tomada del nivel 2 era si cabe más joven pues suministró una fecha de $30.210 \pm 340$ B.P. (Beta-172344). En principio esas fechas -sin calibrar- podrían ajustarse a la horquilla final del Chatelperronense cantábrico (Menéndez, García y Quesada, 2005: 611) aun cuando resultan bastante jóvenes. En la actualidad resulta mejor mantener estas dataciones en cuarentena, teniendo en cuenta que las últimas dataciones cronológicas registradas en el yacimiento muestran una tendencia a envejecer los depósitos. En este sentido, parece aconsejable mantener bastante prudencia a la hora de interpretar los datos de la columna del Paleolítico superior inicial, y esperar nuevos resultados al respecto.

\section{Fase $V$}

Los depósitos de ladera (Niveles 1-3 exterior):

El capitulo final de la deposición en la zona D se compone de los niveles 1-3 de la terraza. Es el relleno arcilloso que se desprende del proceso de descomposición de calizas y que tras la caída desde cotas elevadas de la terraza dio lugar a la ladera actual. Durante el proceso de relleno arcilloso la boca de la cueva se hallaba casi por completo colmatada y la zona probablemente abandonada como un lugar de hábitat. Pero el carácter derivado no ha impedido una notable integridad industrial: salvo pocas excepciones la mayoría de los restos industriales presentan rasgos bastante similares y encajan en un carácter musteroide. El repertorio instrumental arrastrado hasta los niveles 2 y 3 resulta lo bastante homogéneo como para asegurar una procedencia común. Bien es cierto que hay que mantener cierta prudencia al respecto: por ejemplo, las piezas halladas en las cotas más bajas (en la base del nivel 3) justifican la procedencia derivada, pues son numerosas las piezas y restos de huesos recubiertos por capas brechificadas, pequeñas pero consistentes: las mismas costras halladas entre el material de los niveles $4 a-4 b$, que apuntan hacia la removilización parcial desde niveles subyacentes.

\section{CONCLUSIONES \\ LA GÜELGA EN EL CONTEXTO MUSTERIENSE REGIONAL}

En el estado actual de las investigaciones buena parte del interés que despierta la zona D de La Güelga reside en el 
reconocimiento de ocupaciones musterienses mucho más antiguas de las inicialmente previstas. Las dataciones ${ }^{14} \mathrm{C}$ que hemos obtenido de los niveles $4 b$ exterior y 9 interior permiten incorporar La Güelga de una manera decidida en la nómina de yacimientos cantábricos con un Musteriense pleno. La horquilla de las desviaciones es bastante amplia tal como suele acontecer entre los yacimientos de aquella época, pero grosso modo permite ubicar los niveles $4 \mathrm{~b} / 9$ en el intervalo 43.000-53.000 B.P. (sin calibrar). La mayor parte de esa horquilla se corresponde con el momento del Musteriense pleno, previo al Ilamdo Musteriense final (que situamos en el 50.000-39.000 B.P. siguiendo a Bernardo de Quirós et alii, 2008: 37).

Esta horquilla cronológica coincide con las dataciones de media docena de yacimientos cantábricos. Nos hallamos por tanto ante un marco comparativo relativamente amplio y coherente para entresacar conclusiones. En las tierras asturianas este tramo cronológico está representado por los niveles XIII basal y XIV* superior del abrigo de La Viña (Fortea, 1999). En las comarcas cántabras contamos con cuatro yacimientos para la época: hay una datación para El Mirón 130 (Straus y González Morales, 2003), otra para Covalejos D (Rasines, 2005), dos para los niveles XVIII y XXId de El Esquilleu (Baena et alii, 2005; Jordá et alii, 2008), y finalmente siete para el nivel 20 de El Castillo (Cabrera, Pyke-Tay y Bernardo de Quirós, 2004). En las tierras del País Vasco disponemos de dataciones para el nivel B de Axlor (Ríos, 2005), los niveles Smk-1 y Amk de Arrillor (Hoyos, Sáez de Buruaga y Ormazabal, 1999) y el nivel 3/4 de Kurtzia (Muñoz, Sánchez y Ugarte, 1990).

Pero probablemente la referencia más próxima para el nivel $4 b$ exterior de La Güelga (no tanto cronológico como cultural) sea el registro neandertal de la Galería del Osario de El Sidrón (Fortea et alii, 2003, 2007). Las razones para emparentar estos dos yacimientos son numerosas si bien sus dataciones no son estrictamente contemporáneas: la cercanía territorial entre los dos yacimientos, pertenencia a la misma cuenca fluvial del Sella y amplias facilidades para la comunicación, son argumentes muy convincentes para buscar comparaciones entre los dos yacimientos. En sentido estricto las dataciones obtenidas en la Galería del Osario ( ${ }^{14} \mathrm{C}$ AMS sobre restos humanos) son más jóvenes que las suministradas por La Güelga. De acuerdo con las noticias disponibles en este momento, las dataciones de El Sidrón son las siguientes (sin calibrar): $37.300 \pm 830$ B.P. (Beta 192066), 38.240 \pm 890 B.P. (Beta 192067) y $40.840 \pm 1.200$ B.P. (Beta 192065). El promedio calibrado de esas fechas se sitúan en el $43.129 \pm 129$ cal. B.P. (LazuelaFox et alii, 2005, ver también Rosas et alii, 2006). A modo de comparación, el promedio obtenido para el nivel $4 \mathrm{~b}$ de La Güelga mediante calibraciones se sitúa grosso modo en la horquilla 46.000-56.000 B.P. cal. (con las reservas necesarias por las limitaciones de calibración para tan altas cronologias).

Disponemos de otro referente territorial muy próximo para La Güelga, pero se halla todavía en un estadio de estudio preliminar. Se trata del abrigo de Sopeña, situado solo a unos pocos kilómetros aguas arriba del río Güeña. La gran cercanía con La Güelga convierte este yacimiento en el referente más inmediato, si bien no se han publicado todavía las dataciones radiocarbónicas, por lo que no es posible una comparación rigurosa. Teniendo en cuenta que la secuencia de ocupación del abrigo se ha calificado por ahora como un "Paleolítico medio tardío" (Pinto-Llona, Clark y Miller, 2006: 197), podría ser posterior a lo que se ha reconocido en La Güelga. Esta tesitura convertiría este yacimiento en una referencia clave para las ocupaciones musterienses más antiguas conocidas hasta el momento en la zona del medio Sella. Lo que resulta a todas luces cierto, es que la concentración de los yacimientos musterienses que salpican los valles interiores de la cuenca del Sella (valle del Piloña al occidente; del Güeña a oriente) es una prueba indudable de la creciente importancia de esta peculiar región del oriente de Asturias para la comprensión del Musteriense cantábrico desde el 50.000 B.P.

\section{BIBLIOGRAFÍA}

Baena, J.; Carrión, E.; Ruiz, B.; Ellwood, B.; Sesé, C.; Yravedra, J.; Jordá, J.; Uzouiano, P.; Velázouez, R.; Manzano, I.; Sánchez-Marco, A. y HeRnÁndeZ, F., 2005: "Paleoecología y comportamiento humano durante el Pleistoceno Superior en la comarca de la Cueva de El Esquilleu (Occidente de Cantabria, España)". En R. Montes y J.A. Lasheras (Eds), Neandertales cantábricos, estado de la cuestión, Monografias del Museo Nacional y Centro de Investigación de Altamira, 20, Ministerio de Cultura, Santander, pp. 461-487.

Baena, J.; Carrión, E. y Velázouez, R., 2006: "Tradición y coyuntura: claves sobre la variabilidad del Musteriense occidental a partir de la Cueva del Esquilleu". En V. Cabrera, Fdco. Bernardo de Quirós y J.M. Maíllo (Eds. Científicos), En el centenario de la Cueva de EI Castillo: El ocaso de los Neandertales, Centro Asociado UNED de Cantabria, Santander, pp. 249-267.

Bernardo de Quirós, Fdco.; Arrizabalaga, A.; Maillo, J.M. e Iriarte, M־.J., 2008: "La transición paleolítico medio-superior en la región centro-oriental de la Cornisa cantábrica". Espacio, Tiempo y Forma, Serie I, Nueva época, Prehistoria y Arqueología, I, pp. 33-46.

BINFORD, L.R., 1978: "Dimensional analysis of behaviour and site structure:learning from an Eskimo hunting stand". American Antiquity, 43 (3), pp. 330-361.

BinfoRd, L.R., 1988: En busca del pasado. Crítica. Barcelona.

Bronk Ramsey, C.B.; Higham, T.F.G.; Bowles, A. y Hedges, R., 2004: "Improvements to the pretreatment of bone at Oxford". Radiocarbon, 46 (1), pp. 155-163.

Bronk Ramsey, C.B.; Higham, T.F.G. y Leach, P., 2004: "Towards High-Precision AMS: Progress and Limitations". Radiocarbon, 46 (1), pp. 17-24.

Cabrera, V., 1984: El yacimiento de la Cueva de "El Castillo» (Puente Viesgo. Santander). Bibliotheca Praehistorica Hispana, XXII. Instituto Español de Prehistoria (CSIC). Madrid. 
Cabrera, V.; Pyke-Tay, A.; y Bernaldo de Quirós, FdCO., 2004: "Trends in Middle Paleolithic settlement in Cantabrian Spain: The Late Mousterian at Castillo Cave". Settlement Dymanics of the Middle Paleolithic and Middle Stone Age, vol. II, Kerns Verlag, Tubingen, pp. 437-460.

Cabrera, V.; Maillo, J.M. y Bernardo de Quirós, Fdco., 2000: "Esquemas operativos laminares en el Musteriense final de la cueva del Castillo (Puente Riesgo, Cantabria)". Espacio, Tiempo y Forma, Serie I, Prehistoria y Arqueología, 13, pp. 51-78.

CARRIÓN, E. y BAENA, J., 2005: "El Habario: una ocupación musteriense al aire libre en los Picos de Europa". En R. Montes y J.A.Lasheras (Eds), Neandertales cantábricos, estado de la cuestión. Monografias del Museo Nacional y Centro de Investigación de Altamira, 20, Ministerio de Cultura, Santander, pp. 443-460.

Chacón, Ma.G. y Fernández-LASO, Ma.C., 2007: "Modelos de ocupación durante el Paleolítico medio: El nivel K del Abric Romani (Capellades, Barcelona, España)". Complutum, 18, pp. 47-60.

FORTEA, J., 1995: "Abrigo de La Viña. Informe y primera valoración de las campañas 1991 a 1994". Excavaciones Arqueológicas en Asturias 1991-94, Servicio de Publicaciones de la Consejería de Educación, Cultura, Deportes y Juventud, Oviedo, pp. 31-41.

FoRTEA, J., 1999: "Abrigo de La Viña. Informe y primera valoración de las campañas 1995 a 1999". Excavaciones Arqueológicas en Asturias 1995-98, Servicio de Publicaciones de la Consejeria de Educación, Cultura, Deportes y Juventud, Oviedo, pp. 19-32.

Fortea, J.; Rasilla, M. de la, Martinez, E.; Sánchez-Moral, S.; Cañaveras, J.C.; Cueva, S.; Rosas, A.; Soler, V.; Castro, J.; Torres, T.; Ortiz, J.E.; Julià, R.; BADAL, E.; AltunA, J. y Alonso, J., 2003: "La Cueva de El Sidrón (Borines, Piloña, Asturias). Campañas arqueológicas de 2000 a 2002". Estudios Geológicos, 59 (1-4), pp. 159-179.

Fortea, J.; Rasilla, M. de la, Martinez, E.; Sánchez-Moral, S.; Cañaveras, J.C.; Cueva, S.; Rosas, A.; Soler, V.; Castro, J.; TorRes, T.; Ortiz, J.E.; JuLIÀ, R.; BADAL, E.; Altuna, J. y Alonso, J., 2007: "La Cueva de El Sidrón (Borines, Piloña, Asturias). Campañas arqueológicas de 2000 a 2002". Excavaciones arqueológicas en Asturias 1999-2002, Servicio de Publicaciones de la Consejería de Educación, Cultura, Deportes y Juventud, Oviedo, pp. 191-205.

HIGHAM, T. F. G.; JACOBI, R.M. y BRONK, C., 2006: "AMS Radiocarbon Dating of Ancient Bone Using Ultrafiltration". Radiocarbon, 48(2), pp. 179-195.

Hoyos, M.; Saenz de Buruaga, A. y OrmazÁbal, A., 1999: "Cronoestratigrafía y paleoclimatología de los depósitos prehistóricos de la cueva de Arrillor (Araba, Pais Vasco)". Munibe (Antropologia-Arkeologia), 51, pp. 137-151.

Jordá, J.F.; Baena, J.; Carral, P.; Garcia-Guinea, J.; Correcher, V. e YraveDRA, J., 2008: "Procesos sedimentarios y diagenéticos en el registro arqueológico del yacimiento pleistoceno de la Cueva de El Esquilleu (Picos de Europa, Norte de España)". Revista Cuaternario y Geomorfología, 22 (3-4), pp. 31-46.

JULIEN, M., 1983: "Annexe II.Témoins relatifs au feu". En Leroi-Gourhan, A. y Brezillon, M.: Fouilles de Pincevent. Essai d'analyse ethnographique d'un habitat magdalénien. (La Section 36). I-Texte. VIIle supplément à Galllia Préhistoire. Éditions du Centre Nacional de la Recherche Scientifique, Paris, pp. 279-294.

Lazuela-Fox, C.; Samprieto, M.L.; Caramell, D.; Puder, Y.; Lari, M.; Calafell, F.; Martinez-Maza, C.; BastiR, M.; ForteA, J.; Rasilla, M.; BertranPeTIT, J. y RoSAS, A., 2005: "Neandertal Evolutionary Genetics; Mithocondrial DNA Data from the Iberian Peninsula". Molecular Biology and Evolution, 22, pp. 1077-1081.

Lerol-Gourhan, A., 1973 : "Structures de combustion et structures d'excavation ". En A. Leroi.-Gourhan (Dir.) : Séminaire sur les structures d'habitat : Témoins de combustion. Étnologie préhistorique. College de France, Éditions du Centre Nacional de la Recherche Scientifique, 52, pp.3-4.

LeRol-GouRHAN, A., 1983: "Structures hétérogénes: Les unités domestiques". En A. Leroi-Gourhan, y M. Brezillon: Fouilles de Pincevent.
Essai d'analyse ethnographique d'un habitat magdalénien. (La Section 36). I-Texte. VII supplément à Galllia Préhistoire. Éditions du Centre Nacional de la Recherche Scientifique, Paris, pp. 215256

Maroto, J.; Vaquero, M.; Arrizabalaga, A.; Baena, J.; Carrión, E.; JordÁ, J.J.; Martinón, M.; MenÉndez, M.; Montes, R. y Rosell, J., 2005: "Problemática del final del Paleolítico Medio en el Norte Peninsular". En R. Montes y J.A. Lasheras (Eds), Neandertales cantábricos, estado de la cuestión. Monografías del Museo Nacional y Centro de Investigación de Altamira, 20, Ministerio de Cultura, Santander, pp. 101-114.

Martínez Villa, A., 1986: Carta arqueológica de los concejos de Cangas de Onis y Onis. Memoria de Licenciatura, inédita. Universidad de Oviedo.

Menéndez, M. y Martínez, A., 1992a: "Una tibia con ciervas grabadas de la Cueva de La Güelga, Cangas de Onis, Asturias". Zephyrus, XLIVXLV, pp. 65-76.

Menéndez, M. y Martínez, A., 1992b: "Excavaciones arqueológicas en la Cueva de La Güelga. Campañas de 1989-1990". Excavaciones arqueológicas en Asturias (1987-1990), Consejeria de Cultura, Deportes y Juventud, Principado de Asturias, Oviedo, pp. 75-80.

MenÉNDEZ, M.; García, E. y QueSAdA, J.M., 2004: "El Magdaleniense de la Cueva de La Güelga (Narciandi, Cangas de Onis). Avance al conocimiento de su industria lítica". En G. Flor (Ed.): Actas de la XI Reunión Nacional de Cuaternario, Oviedo (Asturias), Asociación Española para el Estudio del Cuaternario, Oviedo, pp. 237-252.

MenéndeZ, M.; Garcia, E. y QuesAdA, J.M., 2007: "Excavaciones en la Cueva de La Güelga (Narciandi, Cangas de Onis). Campañas de 1999 a 2002". Excavaciones arqueológicas en Asturias (1999-2002) , Consejería de Cultura, Deportes y Juventud, Principado de Asturias, Oviedo, pp.63-75.

MenÉndez, M.; Garcí, E. y QuesAdA, J.M., 2005: "Magdaleniense inferior y territorialidad en la Cueva de La Güelga (Asturias). En N. Ferreira (Ed. Cient.): Actas do IV congresso de arqueología peninsular. 0 paleolítico (Faro, 14-19 septiembre 2004). Universidad do Algarbe (Promontorio Monográfica, 20), Faro, pp. 63-71.

Menéndez, M.; Garcia, E. y QuesadA, J.M., 2005: "La transición Paleolítico Medio-Paleolítico Superior en la Cueva de la Güelga (Cangas de Onis, Asturias). Un avance a su registro". En R. Montes y J.A. Lasheras (Eds), Neandertales cantábricos, estado de la cuestión. Monografías del Museo Nacional y Centro de Investigación de Altamira, 20, Ministerio de Cultura, Santander, pp. 589-617.

Menéndez, M.; Garcia, E. y QuesadA, J.M., 2006: "Excavaciones en la Cueva de La Güelga (Cangas de Onís. Asturias)". En V. Cabrera, Fdco. Bernaldo de Quirós y J.M. Maillo (Eds. científicos), En el centenario de la Cueva de El Castillo: El ocaso de los Neandertales, Centro Asociado a la UNED de Cantabria, pp. 209-221.

Menéndez, M.; Quesada, J.M.; JordÁ, J.F.; Carral, P.; TRAncho, G.J.; Garcia, E.; Álvarez, D.; RoJo, J. y Wood, R., 2009: "Excavaciones arqueológicas en la Cueva de La Güelga (Cangas de Onis)". Excavaciones Arqueológicas en Asturias (2003-2006). Consejería de Cultura, Deportes y Juventud, Principado de Asturias, Oviedo, pp. 97-209.

MuÑoz, M.; SÁNChEZ, M. F. y UGARTE, F., 1990: "El entorno geoambiental del yacimiento arqueológico de Kurtzia. Sopela-Barrika. Costa occidental de Bizkaia". Munibe (Ciencias Naturales), 41, pp. 107115.

Pinto-Llona, A. C.; Clark, G.; y MilleR, A., 2006: "Resultados preliminares de los trabajos en curso en el abrigo de Sopeña (Onis, Asturias)". En V. Cabrera, Fdco. Bernardo de Quirós y J.M. Maillo (Eds. Científicos), En el centenario de la Cueva de El Castillo: El ocaso de los Neandertales, Centro Asociado a la UNED de Cantabria, pp. 193-207.

RASINES, P., 2005: El final de la Transición. Dataciones de las primeras ocupaciones del Paleolítico Superior en el centro de la Región Cantábrica. En R. Montes y J.A.Lasheras (Eds), Neandertales cantábricos, estado de la cuestión. Monografías del Museo Nacional y 
Centro de Investigación de Altamira, 20, Ministerio de Cultura, Santander, pp. 577-587.

Ríos J., 2005: "Características de la producción lítica al final del Paleolítico Medio en el País Vasco. El caso del Nivel B de Axlor (Dima, Bizkaia). En R. Montes y J.A.Lasheras (Eds), Neandertales cantábricos, estado de la cuestión. Monografias del Museo Nacional y Centro de Investigación de Altamira, 20, Ministerio de Cultura, Santander, pp. 333-348.

Rosas, A.; Martinez-Maza, A.; Bastir, M.; Garcia-Tabernero, A.; LazuelaFox, C.; Huguet, R.; ORTIZ, J.E.; JuLIÄ, R.; SOleR, V.; ToRres, T.de, MaRtinez, E.; Cañaveras, J.C.; Sánchez-Moral, S.; Cuezva, S.; Lario, J.; Santamarí, D.; Rasilla, M. y ForteA, J., 2006: "Paleobiology and comparative morphology of a late Neandertal simple from El Sidrón, Asturias, Spain". Proceedings of the Nacional Academy of Sciences, 103, pp. 19.266-19.271.

SÁNCHEZ, G. y MAillo, J.M., 2006: "Soportes laminares en el Musteriense final cantábrico: el nivel 20e de la cueva de El Castillo (Cantabria)". En J.M. Maillo y E. Baquedano (Eds.), Zona Arqueológica, 7, Miscelánea en homenaje a Victoria Cabrera, vol. I, Museo Arqueológico Regional, Alcalá de Henares, pp. 274-279.

SAnguino, J. y Montes, R., 2001: "El Pendo 1994-2000. Conclusiones. En R. Montes y J. Sanguino (Dirs.): La Cueva de El Pendo. Actuacio- nes Arqueológicas 1994-2000. Ayuntamiento de Camargo; Gobierno de Cantabria; Parlamento de Cantabria: Santander, pp. 275278.

Straus, L.G. y González Morales, M., 2003: "El Mirón Cave and the 14C chronology of Cantabrian Spain". Radiocarbon, 45 (1), pp. 41-58. Vaquero, M.; Maroto, J.; Arrizabalaga, A.; Baena, J.; Baquedano, E.; Carrión, E.; JoRdÁ, J.F.; MARtinón, Ma.; MenÉndez, M.; Montes, R. y Rosell, J., 2006: "The Neandertal-Modern Human Meeting in Iberia: A Critical View of the Cultural, Geopraphical and Cronological Data". En N.J. Conrad (Ed): When Neandertals and Modern Human Met. Tubingen, Kerns Verlag, pp. 419-439.

Yravedra, J.; BaenA, J.; ArRizabalaga, A. e Iriarte, M.J., 2005: "El empleo del material óseo como combustible durante el Paleolítico Medio y Superior en el Cantábrico. Observaciones experimentales". En R. Montes y J.A. Lasheras (Eds), Neandertales cantábricos, estado de la cuestión. Monografías del Museo Nacional y Centro de Investigación de Altamira, 20, Ministerio de Cultura, Santander, pp. 369-383.

ZILHÃO, J., 2006: "Chronostratigraphy of the Middle-to-Upper Paleolithic Transition in the Iberian Peninsula". Pyrenae (Revista de Prehistòria i Antiguitat de la Mediterrànea occidental), 37 (1), pp. 7-84. 